
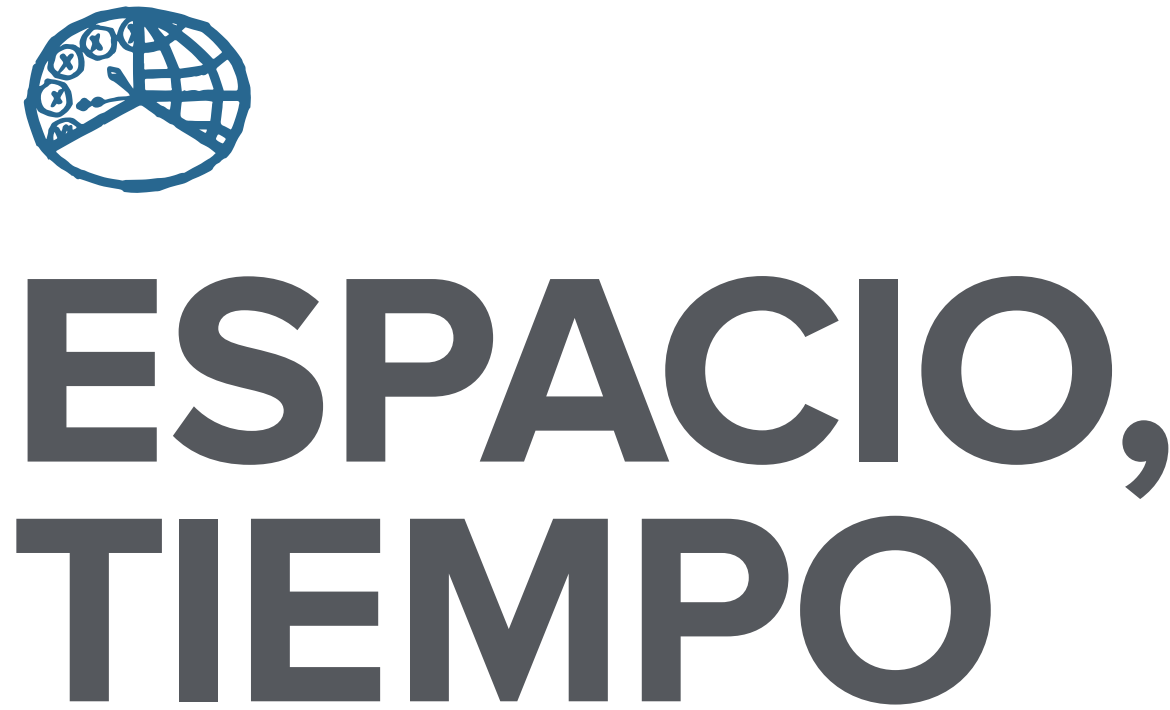

AÑO 2020

NUEVA ÉPOCA

ISSN $1130-4715$

E-ISSN 2340-1478
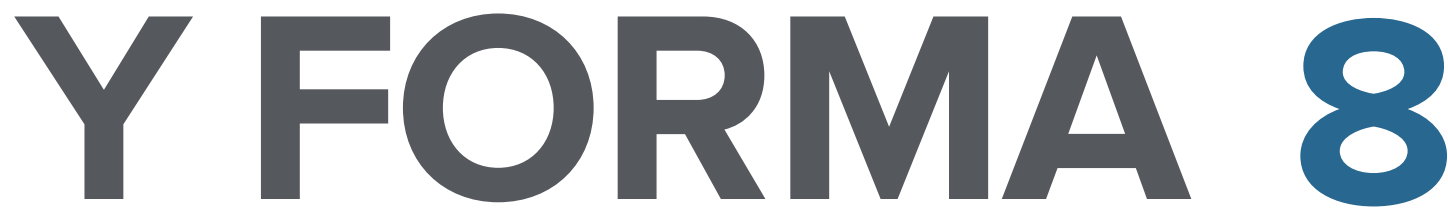

SERIE VII HISTORIA DEL ARTE

REVISTA DE LA FACULTAD DE GEOGRAFÍA E HISTORIA

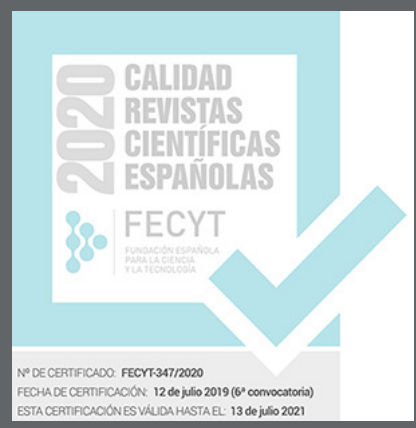




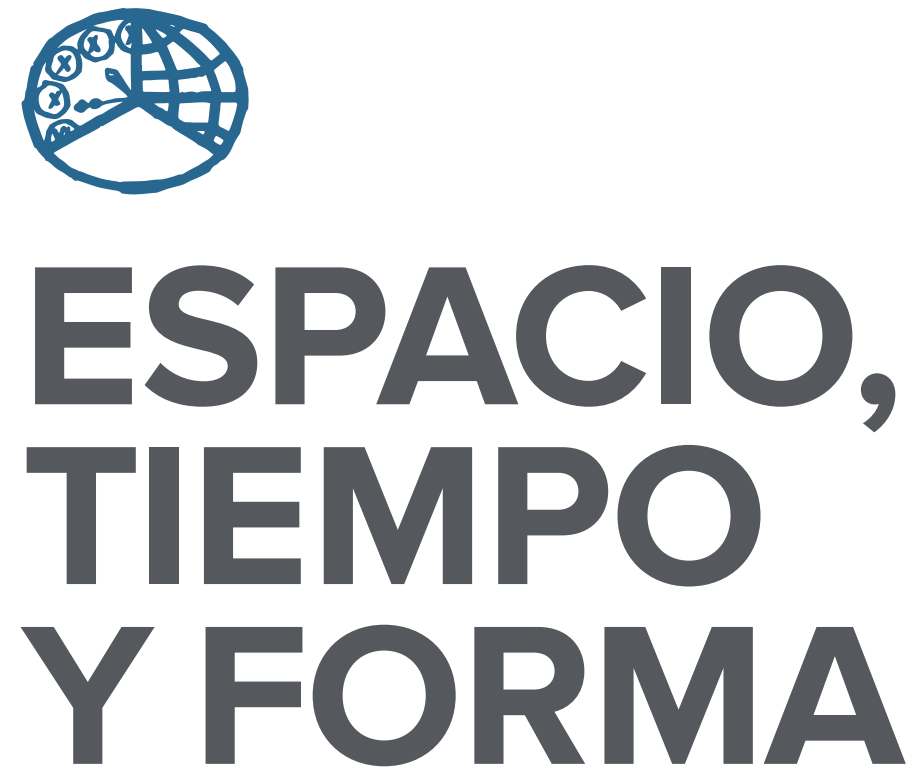

AÑO 2020

NUEVA ÉPOCA

ISSN $1130-4715$

E-ISSN 2340-1478

SERIE VII HISTORIA DEL ARTE

REVISTA DE LA FACULTAD DE GEOGRAFÍA E HISTORIA

DOI: http://dx.doi.org/10.5944/etfvii.8.2020

\section{UกED}

UNIVERSIDAD NACIONAL DE EDUCACIÓN A DISTANCIA 
La revista Espacio, Tiempo y Forma (siglas recomendadas: ETF), de la Facultad de Geografía e Historia de la UNED, que inició su publicación el año 1988, está organizada de la siguiente forma:

$$
\begin{aligned}
& \text { SERIE I - Prehistoria y Arqueología } \\
& \text { SERIE II - Historia Antigua } \\
& \text { SERIE III - Historia Medieval } \\
& \text { SERIE IV - Historia Moderna } \\
& \text { SERIE V - Historia Contemporánea } \\
& \text { SERIE VI - Geografía } \\
& \text { SERIE VII - Historia del Arte }
\end{aligned}
$$

Excepcionalmente, algunos volúmenes del año 1988 atienden a la siguiente numeración:

$$
\begin{aligned}
& \mathrm{N}^{\circ} 1 \text { - Historia Contemporánea } \\
& \mathrm{N}^{\circ} 2 \text { - Historia del Arte } \\
& \text { N. }{ }^{\circ} 3 \text { - Geografía } \\
& \mathrm{N} .^{\circ} 4 \text { - Historia Moderna }
\end{aligned}
$$

ETF no se solidariza necesariamente con las opiniones expresadas por los autores.

UNIVERSIDAD NACIONAL DE EDUCACIÓN A DISTANCIA

Madrid, 2020

SERIE VII · HISTORIA DEL ARTE (NUEVA ÉPOCA) N. ${ }^{\circ} 82020$

ISSN $1130-4715 \cdot E-I S S N 2340-1478$

DEPÓSITO LEGAL

$M-21.037-1988$

URL

ETF VII · HISTORIA DEL ARTE · http://revistas.uned.es/index.php/ETFVII

DISEÑO Y COMPOSICIÓN

Carmen Chincoa Gallardo · http://www.laurisilva.net/cch

Impreso en España · Printed in Spain

(c) (i) () Esta obra está bajo una licencia Creative Commons 


\section{MISCELÁNEA • MISCELLANY}





\title{
LA PORTADA DE LA NAVIDAD EN LA \\ IGLESIA ROMÁNICA DE SANTO DOMINGO \\ DE SILOS (BURGOS): ANÁLISIS DE UN \\ PROGRAMA ICONOGRÁFICO ROMÁNICO INSPIRADO POR LA LITURGIA HISPANA
}

\section{THE CHRISTMAS PORTAL IN THE ROMANIC CHURCH OF SANTO DOMINGO DE SILOS (BURGOS): ANALYSIS OF A ROMANESQUE ICONOGRAPHIC PROGRAM INSPIRED BY THE HISPANIC LITURGY}

\author{
Rodrigo Antolín Minaya \\ Recibido: 12/01/2020 - Aceptado: 03/04/2020 \\ DOI: http://dx.doi.org/10.5944/etfvii.2020.26361
}

\begin{abstract}
Resumen
La puerta septentrional de la iglesia románica de Silos, hoy desaparecida, contaba con un programa decorativo único en el arte románico. El presente trabajo pretende analizar la forma en la que la antigua liturgia hispana fue capaz de condicionar su mensaje iconográfico. Para esto se propondrán relaciones entre los relieves y los manuscritos hispanos que, finalmente, nos permitirán considerar el ciclo de la Navidad del antiguo rito como la inspiración del programa decorativo.
\end{abstract}

Palabras clave

Portada románica; Tímpano; Liturgia hispana; Silos; Iconografía románica.

\begin{abstract}
The north entrance of the Romanesque church of Silos, now disappeared, had a unique decorative programme in Romanesque art. The present work seeks to analyze the way in which the ancient Hispanic liturgy was able to condition its iconographic message. To this end, we propose relationships between the sculptures and Hispanic manuscripts, which will finally allow us to consider the Christmas cycle of the ancient rite as the inspiration for the decorative programme.
\end{abstract}

Keywords

Romanesque portal; tympanum; Hispanic liturgy; Silos; Romanesque iconography.

1. Profesor de Educación Secundaria Obligatoria. C.e.: rodrigoantolinı@hotmail.com ORCID: <https://orcid.org/0000-0003-2351-834X>. 


\section{INTRODUCCIÓN}

En el año I75I el monasterio de Santo Domingo de Silos iniciaba el proceso de construcción de una nueva iglesia neoclásica que suponía el desmantelamiento definitivo de su antiguo templo románico. La reforma del edificio supuso la desaparición de una de las construcciones más significativas del primer románico castellano que, a lo largo del tiempo, se había ido enriqueciendo con sucesivas ampliaciones ${ }^{2}$. El presente trabajo se dirige al análisis de uno de los elementos que desaparecieron en aquel proceso de reforma arquitectónica, concretamente la portada que se abría en su lado norte (FIGURA I) y que se convirtió, a finales del siglo XII, en soporte de un excepcional programa iconográfico que no se repite en ninguna otra portada del románico hispano.

Los elementos decorativos de aquel acceso se conocen gracias a la descripción del edificio que hizo Jerónimo Nebreda ${ }^{3}$ antes de su destrucción y, sobre todo, gracias al hallazgo del tímpano casi completo en I9644 (FIGURA 2). Con estas dos fuentes se pudo confirmar la existencia de una original portada que se encontraba decorada con seis escenas sobre la vida de Cristo; la

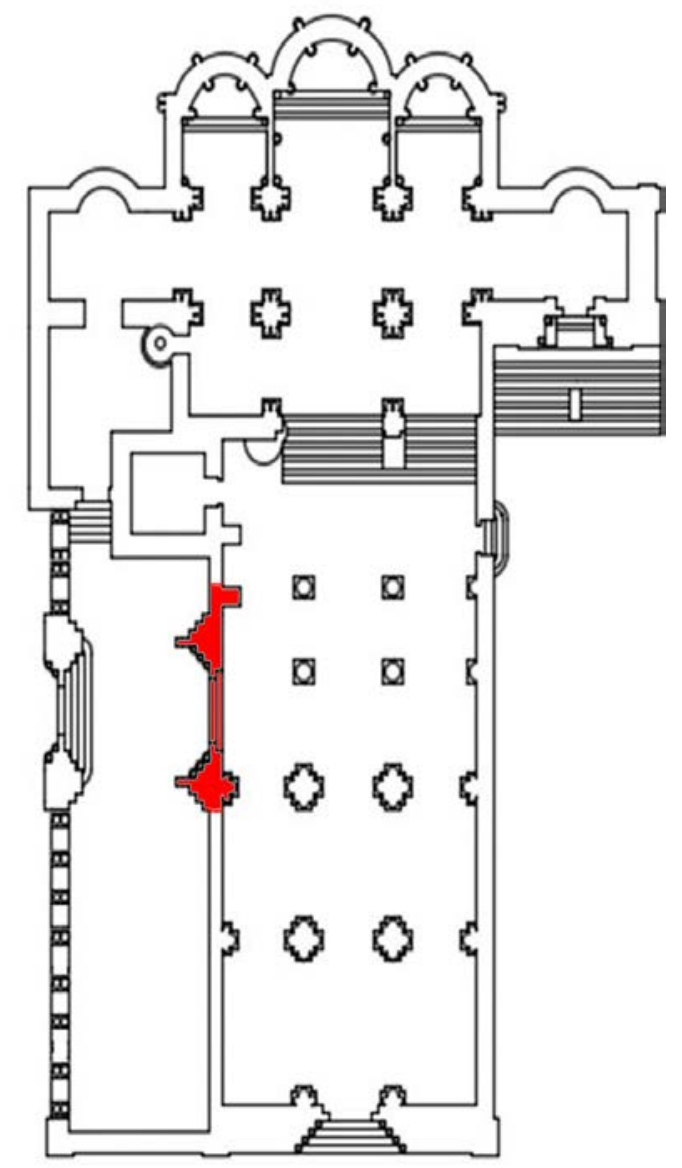
Natividad, la Adoración de los Pastores, la

FIgura 1: PLANTA DE LA DESAPARECIDA IGLESIA ROMÁNICA DE SILOS CON LA PORTADA NORTE MARCADA EN ROJO. Dibujo del autor

2. Sobre las fases constructivas del monasterio de Silos, ver: BANGO TORviso, Isidro: «La iglesia antigua de Silos: del prerrománico al románico pleno», en El románico en Silos: IX centenario de la consagración de la iglesia y el claustro, 1088-1988. Santo Domingo de Silos, Abadía de Silos, 1990, pp. 317-362; Senra Gabriel y Galán, José Luis: «Santo Domingo de Silos: New Interpretive Suggestions for the Medieval Church (1041-1143)», en Church, State, Vellum, and Stone: Essays on Medieval Spain in Honor of John Williams. Leiden/Boston, Brill, 2005, pp. 329-372; SenRA Gabriel y GaláN, José Luis: «El monasterio de Santo Domingo de Silos y la secuencia temporal de una singular arquitectura ornamentada», en Siete maravillas del románico español. Aguilar de Campoo, Fundación Santa María la Real, 2009, pp. 193-226; Palomero Aragón, Félix: «San Sebastián de Silos: la iglesia dedicada o consagrada en torno a 1088 a través de la documentación y los restos arqueológicos», Imago temporis. Medium Aevum, 7 (2013), pp. 476-498; ORduña CuEvas, María: «Una aproximación a la topografía claustral del monasterio de Santo Domingo de Silos (s. XI-XII)», Revista Historia Autónoma, 6 (2015), pp. 11-27.

3. Jerónimo Nebreda fue abad de Silos entre 1572 y 1578. En algún momento de su mandato recogió una breve descripción del antiguo monasterio que después presentaremos con detalle. El fragmento se conserva por una transcripción del siglo XIX en: Ferotin, Marius: Histoire de l'Abayye de Silos. París, Ernest Léroux, 1897, pp. 358-361.

4. Sobre el tímpano y las circunstancias de su hallazgo, ver: Ocón Alonso, Dulce: «La Presentación en el templo de la puerta norte de la iglesia del monasterio de Santo Domingo de Silos y su relación con algunos paradigmas artísticos del mundo mediterráneo», en Alfonso VIII y Leonor de Inglaterra: confluencias artísticas en el entorno de 1200. Madrid, Universidad Complutense de Madrid, 2017, pp. 315-356. 
Presentación en el Templo, la Adoración de los Magos, las Bodas de Caná y la Matanza de los Inocentes.

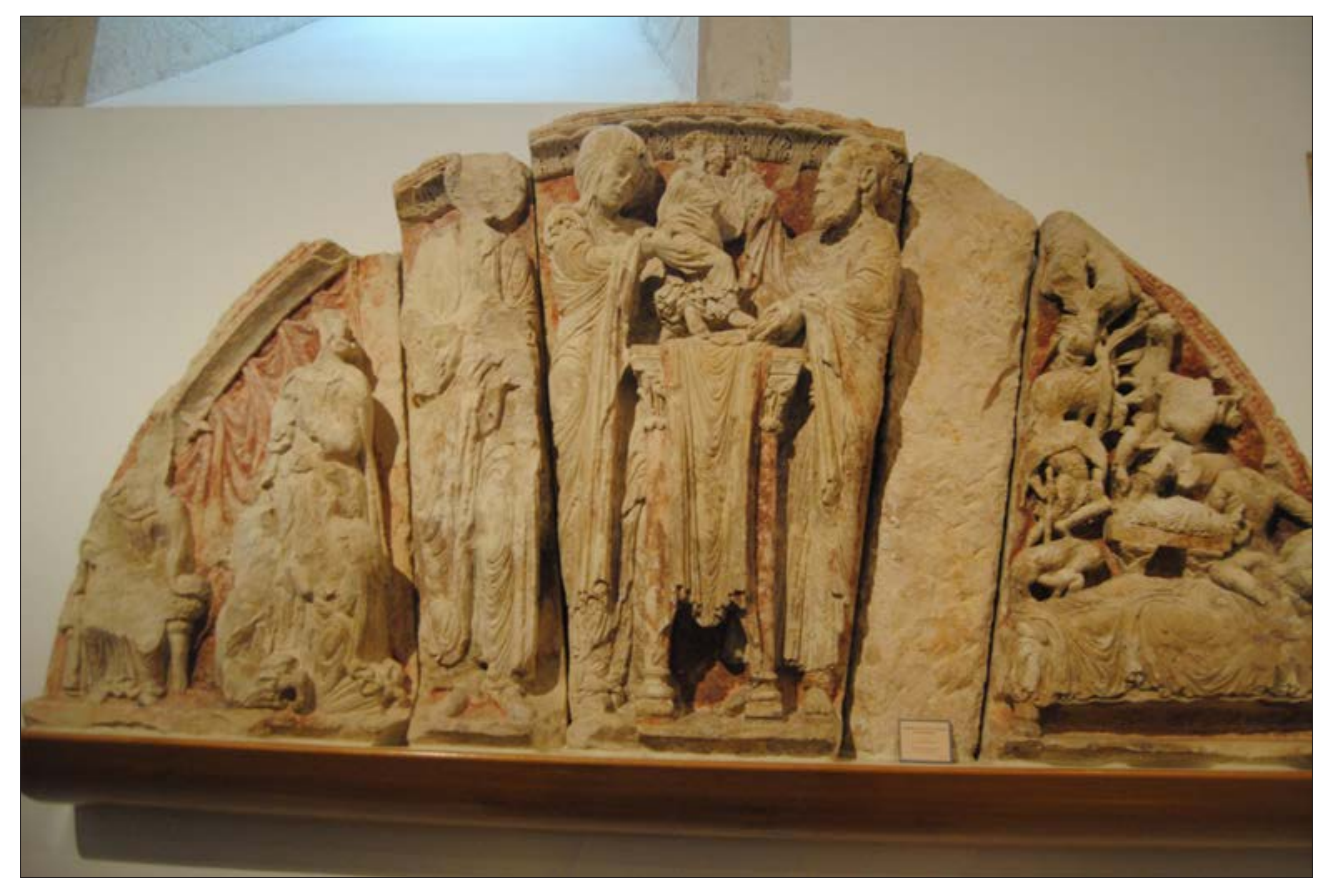

FIgURA 2. tímpano de LA pORTAdA nORTE, MUSEO de Silos. Fotografía: Fernando García Gil

El hallazgo arqueológico del tímpano dio lugar una publicación pionera de Joaquín Yarza ${ }^{5}$ en 1973 que, desde entonces, supuso la base de todos los trabajos posteriores que han analizado el conjunto escultórico. Aquel autor, a nivel iconográfico, consideró el programa decorativo como un «ciclo de Infancia sobre los testimonios terrenos de Cristo» y, a pesar de que varios elementos no encajan en aquella interpretación, la propuesta apenas se ha sometido a pequeñas revisiones que nunca se han alejado de la interpretación del programa decorativo como un ciclo de Infancia ${ }^{6}$.

El objetivo de este trabajo es someter a revisión aquella propuesta imperante y plantear una nueva interpretación que pudiera dar respuesta a todos los elementos que integran el conjunto. En esta línea va a resultar muy expresiva la relación que existe entre el programa decorativo y la antigua liturgia hispana, con la que va a compartir, como más adelante explicaremos, una idéntica secuencia de pasajes

5. YARZA LuACES, Joaquín: «Nuevos hallazgos románicos en el monasterio de Silos», Goya, revista de arte, 96 (1970), pp. 342-345.

6. Muchos trabajos mantienen la denominación de Tímpano de los Testimonios para esta pieza: FronTón SıMóN, Isabel: «El pórtico de la iglesia románica del monasterio de Silos: Datos para la reconstrucción iconográfica de su portada exterior», Boletín del Museo e Instituto Camón Aznar, 64 (1996), p. 65; Valdez Del Álamo, Elizabeth: «Witnesses to the Faith in the pórtico of Santo Domingo de Silos», en Imágenes y promotores en el arte medieval: Miscelánea en homenaje a Joaquín Yarza Luaces, 2001, Barcelona, Universitat Autònoma de Barcelona, p. 222; Bото VARELA, Gerardo: «El santo de Silos: monumenta domésticos, hechuras hagiográficas y expansión devocional (s. XIXIV)», en Hagiografía peninsular en els segles medievals. Lleida, Universitat de Lleida, 2008, p. 45. 
dentro del denominado Tiempo de Navidad; un ciclo litúrgico de tan solo catorce días que va a concentrar, en el mismo orden, todos los pasajes que se trasladan a la portada. Además, en el rico patrimonio bibliográfico del monasterio se conserva aún un manuscrito hispano, el Liber Commicus silense o parisiense ${ }^{7}$, que recoge con exactitud la secuencia de pasajes que se trasladan a la portada, constituyendo un ejemplo de aquellas fuentes litúrgicas que pudieron inspirar el programa iconográfico del acceso.

Antes de argumentar nuestra propuesta vamos a exponer, de forma muy breve, los dos soportes que son la base de nuestra investigación, esto es; la portada norte y el Liber Commicus silense.

\section{LA PORTADA NORTE}

La portada septentrional de Silos, situada junto a la tumba de su santo, estuvo precedida por una galería porticada que conectaba el templo con el núcleo de población y llegó a convertirse, en términos de afluencia de fieles, en el principal acceso de la iglesia.

Los relieves de esta portada presentan soluciones plásticas relacionadas directamente con las obras del último maestro del claustro bajo, llegando a ser considerados por algunos autores, como Charlotte de Charette, productos de un mismo taller ${ }^{8}$. Las figuras presentan un gran volumen que se enriquece con la multiplicación de pliegues, la individualidad de los rasgos y la variedad de posturas, elementos que ponen de manifiesto la originalidad del escultor para resolver cada uno de los pasajes y nos remiten a los modelos utilizados por el citado segundo maestro de Silos, con el que compartirá, incluso, algunos tipos iconográficos que iremos presentando. Este modelo plástico al que nos referimos ofrece un cierto consenso para la datación de la portada en el último tercio del siglo $\mathrm{XII}^{9}$, momento en el que los talleres del claustro bajo utilizan unos recursos similares.

La primera fuente que nos permitió conocer el programa decorativo del acceso era la citada descripción Nebreda (cerca de 1573):

En este portal hay muchas y diversas figuras, así de bulto como de pincel; en el cual está otra puerta, que es de la iglesia antiquísima... Encima de este arco hay otros tres de

7. El manuscrito original se conserva en la Biblioteca Nacional de París (París, B.N. NAL 2171). Digitalizado en: https://archivesetmanuscrits.bnf.fr/ark:/12148/cc704021

8. Sobre los últimos artistas del claustro bajo de Silos, generalmente denominados «segundo taller» o «segundo maestro", ver: Boto VARELA, Gerardo: Ornamento sin delito: los seres imaginarios del claustro de Silos y sus ecos en la escultura románica peninsular. Burgos, Abadía de Silos, 2001; VAldez Del Álamo, Elisabeth: Palace of the Mind. The Cloister of Silos and Spanish Sculpture of the Twelfth Century. Turnhout: Brepols Publishers, 2012; De CharetTe, Charlotte: La diffusion de l'art du second atelier de sculpture de Silos dans le nord de l'Espagne (Tesis doctoral inédita), Université Michel de Montaigne - Bordeaux III, 2014, en https://www.semanticscholar.org/paper/ La-diffusion-de-l'art-du-second-atelier-de-de-Silos-Charette/46681722b8f6b321b8ec3f503c63318ezcadzebb

9. Frontón Simón, Isabel: El pórtico..., p. 82; Boto Varela, G.: El santo de Silos..., p. 46; De Charette, Charlotte: La diffusion..., pp. 15-16. 
piedra: en el primero mayor grandes bultos, la Natividad, Circuncisión, Adoración de los reyes; en el otro está la muerte de los Inocentes, y en otro alto las bodas del architriclino ${ }^{10}$.

Esta descripción fue la principal fuente para el conocimiento de la antigua portada hasta el hallazgo del tímpano, casi completo, en i964. La pieza, expuesta hoy en el museo del monasterio, se compone de cuatro escenas narrativas que avanzan desde el ángulo derecho al izquierdo y que serían; la Natividad, la Adoración de los Pastores, la Presentación en el Templo y la Adoración de los Magos. Esta secuencia de pasajes, que ya había descrito someramente Nebreda, es la que se identificó como un ciclo de Infancia basado en los testimonios, a pesar de que la posición central de la Presentación, que debía ser la última de las escenas representadas, rompía el orden lógico de los ciclos de Infancia, una incongruencia que Joaquín Yarza justificaba como una solución formal del escultor para conseguir una composición más simétrica.

La portada se coronaba con dos arquivoltas que representaban la Matanza de los Inocentes y las Bodas de Caná, las cuales hemos llegado a conocer, principalmente, por la citada descripción de Nebreda, ya que no se conserva ningún resto material que podamos relacionar con la Bodas de Caná y únicamente existe una dovela que pueda atribuirse de forma consensuada a la arquivolta de la Matanza de los Inocentes. La existencia de estos pasajes también implicaba problemas para la lectura iconográfica imperante, ya que las Bodas de Caná se alejaban de toda relación con un ciclo de Infancia al representar una escena de la vida adulta, intentando justificar su presencia en la portada por ser un testimonio de Cristo.

Junto a estos datos expuestos conservamos, también, restos arqueológicos del machón izquierdo de la portada e imágenes antiguas del derecho ${ }^{\text {II }}$. Estas fuentes nos muestran la existencia de tres columnas en las jambas que, necesariamente, debieron coronarse con tres capiteles en cada lado y voltear tres arquivoltas, una más de las descritas por Nebreda. La posible decoración de aquellos capiteles es una completa incógnita, ya que no hemos conservado ningún resto que pueda asociarse de forma fiable a este espacio, aunque podríamos suponer un ciclo decorativo que estuviera vinculado directamente con el conjunto de la parte alta. Los motivos iconográficos que con más frecuencia acompañan al ciclo de Navidad en el románico suelen incorporar episodios como la Anunciación o la Presentación, escenas que ya aparecían unidas en un capitel del claustro realizado por un taller muy cercano al que trabaja en la portada, por lo que no sería improbable que completasen alguno de estos capiteles ${ }^{12}$. Respecto a las arquivoltas, la existencia de una más que las

10. Ferotin, Marius: Histoire..., pp. 358-361.

11. BANGO TORVISO, Isidro: «La iglesia antigua...», p. 339.

12. Sobre el capitel del claustro y su relación con el programa iconográfico del tímpano, ver: VALDEZ DEL ÁlAMO, Elizabeth: «Witnesses...», pp. 223-224; LOZANO LÓPEZ, Esther: «Maestros castellanos del entorno del segundo taller silense: repertorios figurativos y soluciones estilísticas», en Neue Forschungen zur Bauskulptur in Frankreich und Spanien. Berlín, Frankfurt am Main, 2010, p. 202. Tampoco debemos olvidar que otras portadas vinculadas a Silos y que incluían algunos pasajes de la Navidad, como los casos de Santo Domingo de Soria y Moradillo de Sedano, llevaron a sus capiteles el ciclo del Génesis y escenas de la Última Cena respectivamente, al haber representado ya los pasajes de la Anunciación y la Visitación en sus arquivoltas. LozANo López, Esther: Un mundo en imágenes: La 
descritas por Nebreda puede deberse, más que a una omisión, a la alternancia de soportes historiados con otros lisos o decorativos, como sucede en las cercanas portadas de Moradillo de Sedano o Cerezo Río Tirón.

El programa decorativo del acceso norte de Silos suponía una excepción dentro del románico, ya que ninguna otra portada conocida representó un modelo iconográfico similar. No hemos conservado, ni siquiera, portadas románicas que estén presididas por la Presentación en el Templo o que tengan arquivoltas completas con el pasaje de las Bodas de Caná. Estas particularidades nos hacen suponer que nos hallamos ante un programa iconográfico organizado desde las élites culturales de Silos y, por tanto, las principales fuentes debían encontrarse en el propio monasterio.

\section{LOS ECOS DE LA ANTIGUA LITURGIA EN SILOS, EL LIBER COMMICUS Y EL TIEMPO DE NAVIDAD HISPANO}

En el año io8o se hacía oficial el cambio de la liturgia hispana a la romana, un acontecimiento que, sin embargo, no implicaba la desaparición inmediata de los usos y tradiciones anteriores sino que, más bien, era el punto de salida para un lento proceso de transformación que debió dilatarse hasta finales del siglo XII o principios del XIII ${ }^{13}$. Este lento proceso justifica que parte de los centros, pese a adoptar el nuevo rito romano, siguiesen usando durante décadas algunas celebraciones y costumbres hispanas, lo que implicaba la pervivencia de gran parte de su aparato litúrgico y sus antiguos manuscritos, una situación que permitirá que durante todo el siglo XII sigan apareciendo programas decorativos inspirados en la antigua liturgia pese a haber sido abolida ${ }^{\mathrm{I}}$.

portada de Santo Domingo de Soria. Madrid, Fundación Universitaria Española, 2006; CASTRESANA LóPEZ, Álvaro: «Un beato de piedra: el tímpano de Moradillo de Sedano (Burgos)», Estudios mirandeses: Anuario de la fundación cultural «Profesor Cantera Burgos», 35 (2019), pp. 100-139.

13. La mayor parte de los estudios coinciden en señalar que el cambio litúrgico fue un lento proceso que se dilató más de un siglo, provocando la pervivencia de ceremonias, costumbres y manuales del antiguo rito hispano. Así aparece argumentado en: FERNÁNDEZ DE LA CUESTA, Ismael: «La irrupción del canto gregoriano en España. Bases para un replanteamiento», Revista de Musicología, 8/2 (1985), p. 241; Gros I PujoL, Miquel: «Las tradiciones litúrgicas medievales en el noroeste de la península», en IX Centenário da dedicaçâo da Sé de Braga. Congresso Internacional. Actas. Vol. III: Teologia do Templo e Liturgia Bracarense. Braga, Universidade Católica Portuguesa, 1990, p. 108; Vivancos Gómez, Miguel: «El oficio litúrgico en Santo Domingo de Silos», en Silos. Un Milenio. Congreso Internacional sobre la Abadía de Santo Domingo de Silos, Tomo I, espiritualidad. Burgos, Universidad de Burgos, 2003, p. 83; VONES, Ludwing: «La sustitución de la liturgia hispana por el rito romano en los reinos de la península ibérica», en Hispania Vetus: manuscritos litúrgico-musicales: de los orígenes visigóticos a la transición franco-romana (siglos XI-XII). Madrid, Fundación BBVA, 2007, p. 43; ZAPKE, Susana: «Sistemas de notación en la Península lbérica: de las notaciones hispanas a la notación aquitana (siglos IX-XII)», en Hispania Vetus: manuscritos litúrgico-musicales: de los orígenes visigóticos a la transición franco-romana (siglos XI-XII). Madrid, Fundación BBVA, 2007, p. 189; RUBIO SADIA, Juan Pablo: «Introducción del Rito Romano y reforma de la iglesia hispana en el siglo XI: de Sancho III el Mayor a Alfonso VI», en La reforma gregoriana en España: seminario de historia de la iglesia. Madrid, Publicaciones San Dámaso, 2011, p. 57; SÁNCHEZ Domıngo, Rafael: «El rito hispano-visigótico o mozárabe: del ordo tradicional al canon romano», en Patrimonio Inmaterial de la Cultura Cristiana. San Lorenzo de El Escorial, Ediciones Escurialenses, 2013, pp. 222-223.

14. Podemos citar el ejemplo de las pinturas de San Pelayo de Perazancas, de finales del siglo XII; BANGO TORVISO, Isidro: «San Pelayo de Perazancas: Las imágenes de un calendario románico organizadas según la vieja liturgia hispana, y su contexto en el conjunto del programa iconográfico», Anales de Historia del Arte, 4 (1993-1994), pp. 545-558. 
En el caso del monasterio de Silos la pervivencia de aquellas tradiciones litúrgicas hispanas debió ser significativa, condicionando durante varias décadas parte de sus rituales y de su iconografía artística. Este legado hispano entre los muros de la abadía ya fue aludido por Manuel Vivancos, que consideraba que ciertos rituales secundarios se mantuvieron durante décadas ${ }^{15}$, algo que aparece documentado en Silos con celebraciones hispanas que seguían en uso durante el siglo XII a pesar de las prohibiciones, como sucedía con la pervivencia del rito hispano del Lavatorio $^{16}$ o la festivitas Sancte Marie que, según el antiguo calendario litúrgico, seguía celebrándose el I8 de diciembre ${ }^{17}$.

En las esculturas románicas de Silos la liturgia hispana también se sugiere como fuente de inspiración, por ejemplo, en los seis primeros relieves del claustro, donde Malka Ben-Pechat habla de la representación de dogmas inspirados por los viejos usos litúrgicos hispanos ${ }^{\mathrm{I}}$, o en el relieve de la Ascensión, donde Antonio Manuel Pérez exponía la posibilidad de que los textos patrísticos en los que se inspira pudieran transmitirse a través de los manuscritos hispanos conservados en Silos $^{19}$, o en los relieves de Emaús y la Duda de Santo Tomás, donde Otto Werckmeister cita las influencias derivadas de los códices anteriores al cambio litúrgico ${ }^{20}$. Estas propuestas citadas nos indican que la influencia de la liturgia hispana en la escultura de Silos no fue un proceso exclusivo de la portada que analizamos, sino que asistimos a un sistema de relaciones que pudo condicionar otros programas decorativos, o al menos alguno de sus detalles.

Otro de los datos que nos habla del legado de la liturgia hispana en Silos es el importante número de manuscritos antiguos que se conservaron, entre los cuales el Liber Commicus silense es el que mejor conserva la secuencia de pasajes que se traslada a la portada y es, por tanto, en el que centraremos nuestro análisis, sin olvidar que otros manuscritos hispanos pudieron mantener una secuencia de celebraciones semejante. El Liber Commicus era un libro propio de la liturgia hispana que funcionaba como leccionario para la misa e incluía las lecciones, epístolas y evangelios ajustados a cada uno de los periodos del calendario litúrgico hispano ${ }^{21}$. El ejemplar de Silos se data a mediados del siglo XI, conociendo la fecha exacta de su llegada al monasterio gracias a una anotación marginal que indica que fue donado en 1067 por Sancho de Tabladillo ${ }^{22}$.

15. Vivancos Gómez, Miguel: «El oficio litúrgico de Santo Domingo de Silos», en Silos. Un Milenio, Tomo I, Actas del congreso internacional sobre la abadía de Santo Domingo de Silos. Burgos, Universidad de Burgos, 2003, p. 83.

16. Prado, Germán: Historia del rito mozárabe y toledano. Burgos, Abadía de Santo Domingo de Silos, 1928, p. 79.

17. Vivancos Gómez, Miguel: «El oficio...», p. 83.

18. Ben-PECHAT, Malka: «L'iconographie de l'Ascensión dans le programme des six bas reliefs sous une lumière théologique et liturgique», en El románico en Silos. IX centenario de la consagración de la iglesia y el claustro, 1088-1988. Santo Domingo de Silos, Abadía de Silos, 1990, pp. 465-471.

19. PÉreZ, Antonio Manuel: «Fuentes iconográficas de la representación de Cristo del relieve de la Ascensión del Claustro de Silos», Archivo Español de Arte, 320 (2007), pp. 437-440.

20. Wervkmeister, Otto Karl: «The Emmaus and Thomas pillar of the cloister of Silos», en El románico en Silos: IX centenario de la consagración de la iglesia y el claustro, 1088-1988. Santo Domingo de Silos, Abadía de Silos, 1990, pp. 156 y 158.

21. PINelL, Jordi: Liturgia hispánica. Barcelona, Centre de Pastoral Litúrgica, 1998, p. 41.

22. SÁnchez Mariana, Manuel: «Los códices del monasterio de Silos», Boletín de la Institución Fernán González, $63 / 203$ (1983), p. 221. 
Para exponer los argumentos en los que se sustenta este trabajo no vamos a utilizar el manuscrito original, sino que nos serviremos de la publicación del Liber Commicus silense que hizo Germain Morín en $\mathrm{I} 893^{23}$, una obra que resulta una transcripción literal y minuciosa de las páginas del códice de Silos. Esta obra, más accesible para investigadores y lectores, es a la que haremos referencia cuando, de aquí en adelante, citemos las páginas en las que se encuentra cada uno de los pasajes.

El Tiempo de Navidad de la liturgia hispana es un aspecto fundamental para la lectura iconográfica de la portada, ya que se va a convertir, como veremos, en el objeto de la representación. En el rito hispano la Navidad era una sucesión de pasajes que, al igual que sucede en la escultura de la portada, se iniciaba con el nacimiento de Cristo y concluía con la Matanza de los Inocentes ${ }^{24}$. Esa sucesión de acontecimientos se conocía como Tiempo de Navidad y se componía de cuatro celebraciones: Nativitas Domini (25 de diciembre), Diem Circumcisionis (I de enero), Aparittione Domini (6 de enero) y Allisione Infantum (8 de enero) ${ }^{25}$.

El diferente orden de celebraciones que existe entre la Navidad de la liturgia hispana y la de la liturgia romana es lo que nos permite decantarnos por la primera como fuente que inspira el programa iconográfico. Mientras que en el rito hispano el orden de celebraciones coincide con exactitud con el orden en el que las escenas que se tallan en la portada, no va a ocurrir lo mismo con la liturgia romana, ya que allí la celebración de los Inocentes se desplaza al 28 de diciembre y la Presentación en el Templo al 2 de febrero. Estas modificaciones implicarían cambios iconográficos que expondremos detalladamente en el siguiente epígrafe.

\section{RELACIÓN ENTRE EL MANUSCRITO Y LA PORTADA}

Este apartado constituye el verdadero eje de nuestra investigación, ya que es el punto donde argumentamos la relación entre la portada y la liturgia hispana, y desde donde llegaremos a la consideración de este programa decorativo como una representación del ciclo de Navidad que se recogía en la antigua liturgia. Para ilustrar esta relación presentaremos pasaje por pasaje.

\section{LA NATIVIDAD}

La escena del Nacimiento de Cristo es el primer acontecimiento representado en la portada y va a ocupar la parte inferior del ángulo derecho. En el relieve se representa una variante iconográfica que incluye a la Virgen, tumbada tras dar a luz, a la partera Salomé, situada a su espalda, y las figuras de la mula y el buey, hoy

23. Morin, Germain: Liber Comicus; sive, Lectionarius missae quo toletana Eclessia ante annos mille et ducent usutebatur. Universidad de Toronto, 1893. Edición digital en: https://archive.org/details/libercomicussiveoomoriuoft/ page/ng

24. Aguilera López, Salvador; Ivorra Robla, Adolfo: op. cit, pp. 47-54.

25. Sobre las celebraciones indicadas, ver: Aguilera López, Salvador; Ivorra Robla, Adolfo: op. cit., p. 47. 
muy degradas y de las que solo se conserva parte del cuerpo (FIGURA 3).

La mayor parte de los estudios sobre el tímpano coinciden en la posibilidad de que la Virgen estuviese dando el pecho al Niño en su regazo y que hoy se habría perdido por la erosión del relieve ${ }^{26}$, una hipótesis que parece reforzarse por la composición alegórica que aparece sobre los pies de la Virgen con una oveja amamantado a su cría.

En el Liber Commicus silense este pasaje del Nacimiento es el comienzo del ciclo de Navidad y pertenece a la festividad llamada Navitas Domini que se celebraba el día 25 de diciembre. El acontecimiento aparece en la página I9 del Liber Commicus con la lectura del evangelio de Lucas (2, 6-7):

Mientras estaban allí se cumplieron los días del alumbramiento y dio a luz a su hijo primogénito. Lo envolvió en pañales y lo acostó en un pesebre...27.

Como veremos más adelante, todas las escenas esculpidas van a representar los pasajes inspirándose en las lecturas de los

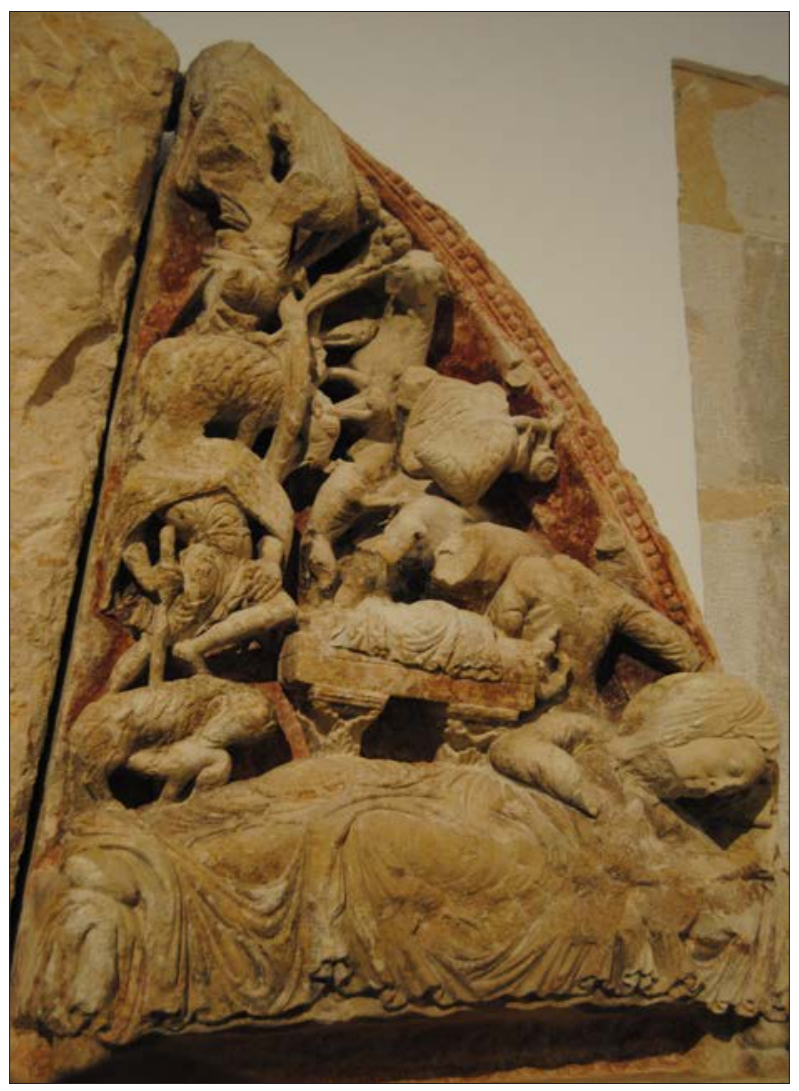

Figura 3. Ángulo con la nATIVIDAd y LA ADORACIÓn de Los PASTORES. Fotografía: Fernando García Gil evangelios de Lucas y Mateo que se utilizan en el Liber Commicus, con la excepción de este episodio de la Natividad, donde sí van a existir diferencias entre la descripción del manuscrito y la forma en que se talla en la portada, ya que allí aparecen personajes (la mula, el buey y la partera) que no se citaban en el códice de Silos ${ }^{28}$. El modelo iconográfico que se utiliza en el tímpano es el resultado de una suma de fuentes diversas que se fueron definiendo durante el periodo altomedieval, provocando que a la descripción del evangelio de Lucas se incorporasen la mula y el buey, tomadas del Pseudo Mateo ${ }^{29}$, y la

26. Yarza LuACES, Joaquín: op. cit., p. 343; Gómez Gómez, Agustín: «La iconografía del parto en el arte románico hispano», Príncipe de Viana, 213 (1998), p. 81; VALDEZ DEL ÁLAMO, Elizabeth: «Witnesses...», p. 228.

27. Original en latín: «Factum est autem, quum esset ibi, impleti sunt dies, ut pareret, et peperit fílium suum primogenitum; et pannis eum involvit et reclinabit eum in praesepio...». Traducción de: Biblia de Jerusalén, Ed. Desclée de Brouwer, 2009.

28. La variante iconográfica utilizada tiene un origen bizantino y durante el románico se extendió por todo el territorio europeo, encontrando modelos iconográficos similares en Italia (basílica de San Zenón de Verona), Francia (la Magdalena de Vezelay) o España (San Juan de Ortega), ver: GonzÁlez HeRnANDo, Irene: «El nacimiento de Cristo», Revista Digital de Iconografía Medieval, 2-4 (2010), pp. 41-59. Sobre las variaciones iconográficas del tema en España, ver: Gómez Gómez, Agustín: «La iconografía...».

29. El evangelio del Pseudo Mateo cita la mula y el buey en su capítulo XIV: «Tres días después de nacer el Señor, salió María de la gruta y se aposentó en un establo. Allí reclinó al niño en un pesebre, y el buey y el asno le adoraron»; Santos Otero, Aurelio: Los evangelios apócrifos. Madrid, Biblioteca de Autores Cristianos, 2005, p. 92. 
figura de la partera, citada en el Protoevangelio de Santiago ${ }^{30}$. Cuando los talleres de Silos inician el trabajo del tímpano esta variante iconográfica ya estaba arraigada su repertorio y lo habían plasmado de aquella forma en uno de los capiteles del claustro ${ }^{31}$. Por tanto, el maestro que acomete los relieves del tímpano, muy cercano a los que trabajan en el claustro, contaba ya con una referencia iconográfica para el desarrollo del pasaje, lo que justifica que el modelo de representación no se ajuste de forma explícita a la lectura del manuscrito, sino que incorpora elementos que derivan de su propio bagaje artístico.

La representación de la escena de la Natividad, como conclusión, tiene su origen en modelos iconográficos que se encontraban definidos previamente en el taller que la ejecuta, por lo que será la única escena de la portada en la que no hay relación directa entre la lectura litúrgica y la forma de representación, a pesar de que en los dos soportes (Liber Commicus y portada) actúa como el arranque de una secuencia de pasajes narrativos vinculados al ciclo de la Navidad.

\section{ADORACIÓN DE LOS PASTORES}

La escena de la Adoración de los Pastores también se sitúa en el ángulo derecho del tímpano, justo encima de la Natividad y relacionada con ella a través de la imagen de un pesebre con el Niño. Esta escena representa muchas figuras en un espacio pequeño que, unido a la degradación del relieve en este sector, hace que sea la composición más difícil de interpretar (FIGURA 4). A pesar de ello aún puede reconocerse la figura de un ángel con las alas extendidas en la parte superior y, bajo él, una maraña de ramas que encierra las figuras de una oveja, una cabra, un perro y dos pastores, uno de ellos en el borde derecho del tímpano y otro arrodillado frente a un pesebre con el Niño envuelto en telas.

La presencia del pesebre, interpretado casi como un altar, suponía un problema para la lectura iconográfica de este sector del tímpano, ya que su existencia implicaba aceptar que la representación del Niño se hacía por duplicado, al existir uno en el

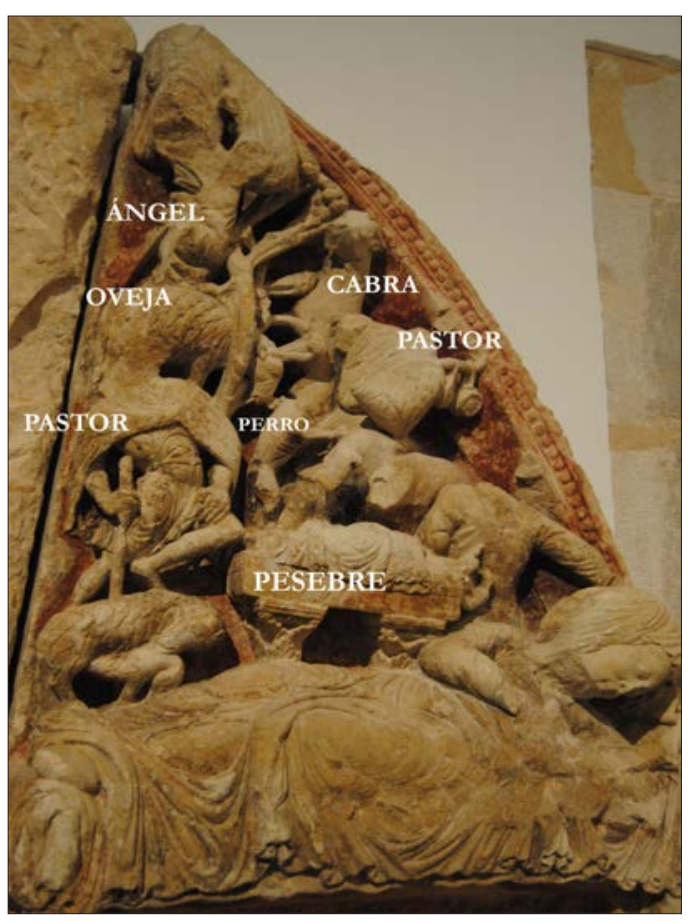

FIGURA 4. ESCENA DE LOS PASTORES CON LOS PERSONAJES QUE APARECEN EN ELLA. Fotografía: Fernando García Gil

30. El Protoevangelio de Santiago cita la partera en el capítulo XIX: «Y entonces una mujer que bajaba de la montaña me dijo: ¿Dónde vas tú? A lo que respondí: Ando buscando una partera hebrea... José respondió: Ven y verás. Entonces la partera se puso en camino con él»; SANTOS OTERo, Aurelio: Los evangelios..., p. 69.

31. Esther Lozano, incluso, llega a considerar que aquel capitel del claustro de Silos pudiera ser el origen de esta variante iconográfica en el románico hispano. Sobre esta afirmación y sobre el capitel aludido, ver: LOZANO LÓPEZ, Esther: «Maestros castellanos...», p. 202; DE ChARETTE, Charlotte: op. cit., pp. 15, 16 y 20. 
pesebre y otro sobre el regazo de la Virgen. La respuesta a esta cuestión se encuentra en la concepción individual de los dos pasajes ya que, pese a coincidir en un mismo espacio, se interpretan como dos episodios individuales que incluyen, por tanto, a un Niño en cada escena, de la misma forma que aparecerá otro en la Presentación y otro más en Adoración de los Magos. Por lo tanto, no sería correcto hablar de una figura que se duplica en una escena sino, más bien, de dos escenas concebidas como pasajes independientes que se integran en un mismo espacio.

En el Liber Commicus el pasaje de los Pastores es, como en la portada, el acontecimiento que sigue al nacimiento de Cristo; de hecho, allí ambos sucesos se recogen en una misma lectura, de igual forma que en la portada se unen en un mismo espacio. El acontecimiento de los Pastores aparece en la página I9 (Lucas 2, 8-I2):

\begin{abstract}
Había en la misma comarca unos pastores, que dormían al raso y vigilaban por turno durante la noche su rebaño. Se les presentó el ángel del Señor; la gloria del Señor los envolvió en su luz y se llenaron de temor. El ángel les dijo: «No temáis, pues os anuncio una gran alegría, que lo será para todo el pueblo: os ha nacido hoy, en la ciudad de David, un salvador, que es el Cristo Señor. Esto os servirá de señal: encontraréis un niño envuelto en pañales y acostado en un pesebre» ${ }^{22}$.
\end{abstract}

La representación del pasaje durante el románico adoptó una cierta libertad compositiva que, en líneas generales, coincide en los personajes representados pero difiere en las composiciones, siendo habitual la inclusión de los pastores, las ovejas y los elementos que, de una u otra forma, evocan a la naturaleza ${ }^{33}$. El monasterio de Silos contaba también con un precedente iconográfico en el capitel de la Natividad del claustro que, en este caso, no va a servir como modelo a la composición, posiblemente porque aquí el artista se vio en la necesidad de desarrollar el tema en un espacio principal y bastante más amplio que el ángulo del capitel del claustro, lo que le obligó a buscar una nueva composición.

En esta situación, el modelo iconográfico del tímpano va a inspirarse directamente en el fragmento del evangelio de Lucas que aparecía en el manuscrito ${ }^{34}$, ya que representa de forma directa todos los elementos que allí se citaban. Tanto en el texto como en la portada la composición está presidida por el ángel que se aparece a los pastores «acampados al raso», una alusión al espacio natural que se evoca en la portada a través de la maraña de ramas que encierra a los personajes y sus rebaños. Del mismo modo el relieve del tímpano se hace eco de la frase en la que

32. Original en latín: «Et pastores erant in regione eadem vigilantes et custodientes vigilias noctis super gregem suum. Et ecce angelus Domini stetit iuxta illos, et claritas dei circumfulsit illos, et timuerunt timore magno. Et dixit illis angelus: Nolíte timere; ecce enim evangelízo vobis gaudium magnum, quod erit omni pópulo, quia natus est vobis hodie Salbator, qui est xps Dominus, in civitatem David. Et hoc vobis signum: invenietis infantem pannis obolutum et positum in praesepio». Traducción de: Biblia de Jerusalén, Ed. Desclée de Brouwer, 2009.

33. La representación del pasaje incluyendo esos elementos podemos encontrarla en todo el territorio peninsular, por ejemplo, en San Miguel de Estella, Santo Domingo de Soria, Burgo de Osma o San Juan de Ortega. En el ámbito europeo también localizamos ejemplos como los de la Magdalena de Vezelay o la portada de la catedral de Ferrara.

34. Otras fuentes iconográficas que se utilizaron durante el románico para este pasaje fueron el Pseudo Mateo y el Evangelio Armenio de la Infancia, ver: Del Amo HorgA, Luz Marina: «La iconografía de la Navidad. Ciclo de la Navidad o Encarnación», en Arte, religiosidad y tradiciones populares. San Lorenzo de El Escorial, Real Centro Universitario Escorial-María Cristina, 2009, p. 246. 
los pastores encontraban al Niño sobre el pesebre, representando ese instante del pasaje con la figura de uno de los pastores arrodillados frente al pesebre. No van a existir en el relieve, por tanto, elementos que pudieran derivar de fuentes diferentes.

Las relaciones plásticas expuestas sirven para mostrar la cercanía entre la portada y el fragmento litúrgico, pero no serían suficientes por sí mismas para considerar el ritual hispano como inspiración del programa, ya que la lectura que recoge el manuscrito (Lucas 2; 8-I2) es común tanto a la liturgia hispana como a la romana, pudiendo haber llegado a la portada a través cualquiera de esas dos vías. Por este motivo, los argumentos que nos llevan a establecer la relación con la liturgia hispana van a ir tomando cuerpo a través del análisis de otras escenas de la portada.

\section{PRESENTACIÓN EN EL TEMPLO}

La escena de la Presentación en el Templo va a ocupar el espacio central del conjunto, convirtiéndose en el único ejemplo conocido en el que este pasaje va a presidir un tímpano románico. La composición aparece dominada por un altar cubierto de telas sobre el cual se sitúa, de nuevo, la figura del Niño. Al lado izquierdo aparece la Virgen ofreciendo al recién nacido y, tras ella, se representa a san José portando algo irreconocible en las manos que, posiblemente, fuesen las tórtolas o pichones. Al lado derecho del altar se representa al anciano Simeón alzando sus brazos hacia el Niño y, tras él, un bloque vacío que debía acoger una figura simétrica a la de san José y que generalmente se identifica como santa Ana (FIGURA 5).

En el Liber Commicus la Presentación en el Templo se celebraba en el Diem Circumcisionis del I de enero y era el acontecimiento que, dentro del ciclo de Navidad, seguía al Nativitis Domini antes descrito. Esta celebración incluía dos acontecimientos unidos en

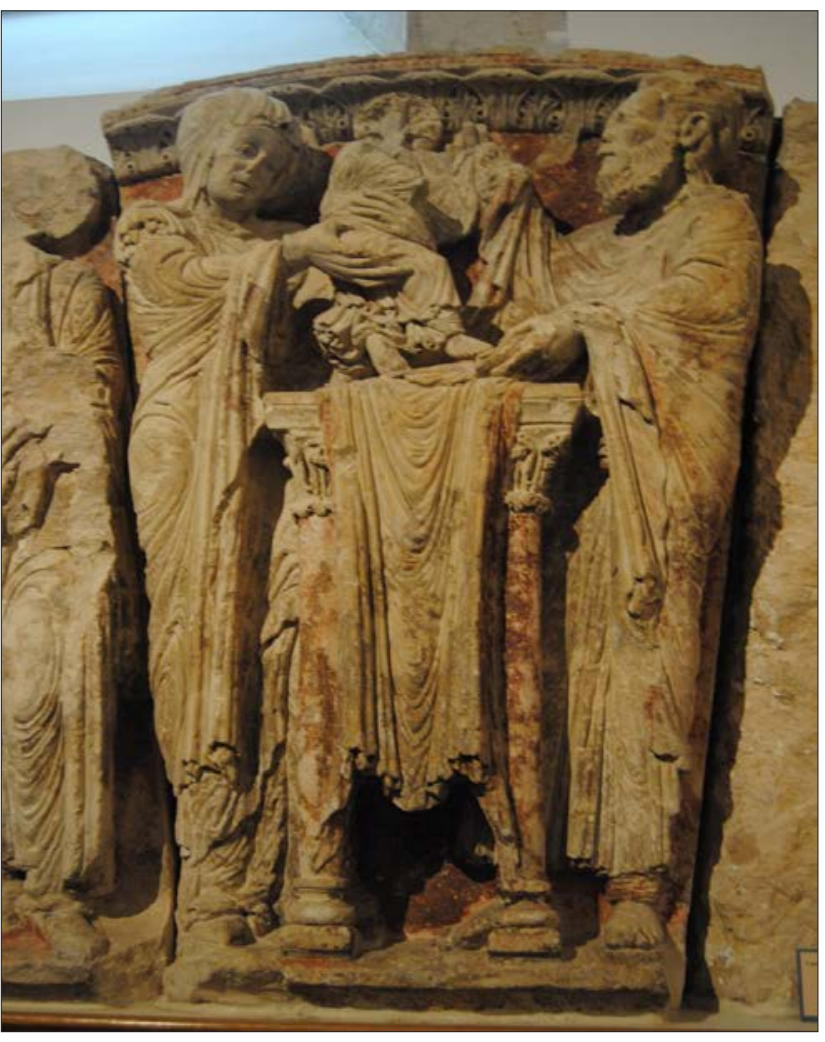

FIGURA 5. DETALLE DE LA ESCEnA CENTRAL CON LA PRESENTACIÓN EN EL TEMPLO. Fotografía: Fernando García Gil una misma lectura: la Circuncisión y la Presentación. Por el título que recibe la festividad se podría pensar que la Circuncisión debía ser el pasaje central de la misa, sin embargo, si nos acercamos al Liber Commicus podemos ver cómo ese acontecimiento toma un carácter secundario y apenas le dedican dos líneas de la lectura, mientras que la verdadera descripción 
de la celebración se centra en la Presentación en el Templo, siendo posiblemente el motivo que llevó al iconógrafo a elegir este acontecimiento para ilustrar la festividad y no el de la Circuncisión. El pasaje se recoge en la página 36 del Liber Commicus (Lucas 2, 22-36):

Cuando se cumplieron los días en que debían purificarse, según la Ley de Moisés, llevaron a Jesús a Jerusalén para presentarle al Señor...

Vivía por entonces en Jerusalén un hombre llamado Simeón. Era una persona justa y piadosa... Cuando los padres introdujeron al niño Jesús, para cumplir lo que la Ley prescribía sobre él, [Simeón] lo tomó en brazos y alabó a Dios...

Había también una profetisa Ana, hija de Fanuel...35.

Volviendo a la relación entre la portada y el manuscrito debemos recordar que la posición de esta escena es la que más problemas generó a Joaquín Yarza en su propuesta iconográfica, ya que en el caso de tratarse de un ciclo de Infancia, como él proponía, este acontecimiento debía haber sido posterior a la Adoración de los Magos y debía, por tanto, aparecer desplazado en el ángulo izquierdo. Esta ruptura del orden narrativo la justificaba como una licencia plástica del escultor para conseguir una composición más simétrica ${ }^{36}$, sin embargo, como ya propusieron Elisabeth Valdez y Dulce Ocón, creemos que el desplazamiento de la escena debe responder a cuestiones preestablecidas y no tanto a soluciones compositivas ${ }^{37}$. De hecho, y dentro de la línea que defendemos, la posición del pasaje en la portada cobra un sentido pleno si consideramos la liturgia hispana como inspiración del programa iconográfico, pues allí esta celebración es, precisamente, la que aparece entre los pasajes de los Pastores y los Magos, en una posición idéntica a la que se representa en la portada. La estructura del programa iconográfico, por tanto, no se ajustaría al orden tradicional de los ciclos de Infancia sino que, más bien, representaría un orden preestablecido de celebraciones litúrgicas.

La posición de la escena, además, nos permite corroborar la liturgia hispana como la fuente más probable del programa decorativo, ya que allí esta celebración tenía lugar el día i de enero, justo antes de la festividad de los Magos. En la liturgia romana el acontecimiento, por el contrario, se trasladó al 2 de febrero por lo que, de haber sido la fuente de referencia para la portada, hubiese sido el último de los acontecimientos representados y no tendría justificación su posición central.

En lo que respecta a los aspectos compositivos de la escena, vemos cómo el modelo de representación vuelve a coincidir plenamente con el texto del manuscrito, incorporando los cuatro personajes que se citaban; Simeón, la Virgen, santa

35. Original en latín: «Et postquam impléti sunt dies purgatiónis eórum secúndum legem Móysis, tulérunt illum in Hierosólymam, ut sísterent Dómino... Et ecce homo erat in lerúsalem, cui nomen Símeon, et homo iste iustus et timorátus... Et cum indúcerent púerum lesum paréntes eius, ut fácerent secúndum consuetúdinem legis pro eo, et ipse accépit eum in ulnas suas et benedíxit Deum... Et erat Anna prophetíssa, fília Phánuel...». Traducción tomada de: Biblia de Jerusalén, Ed. Desclée de Brouwer, 2009.

36. «El hecho de que la escena más destacada sea la Presentación se debe menos a motivos iconográficos que compositivos. El artista se ha servido de ella porque le proporcionaba un buen medio de disponer con cierta simetría el conjunto del tímpano»; YARZA LUACES, Joaquín: op. cit., p. 343.

37. Valdez Del Álamo, Elizabeth: «Witnesses...», p. 225; Ocón Alonso, Dulce: op. cit., p. 323. 


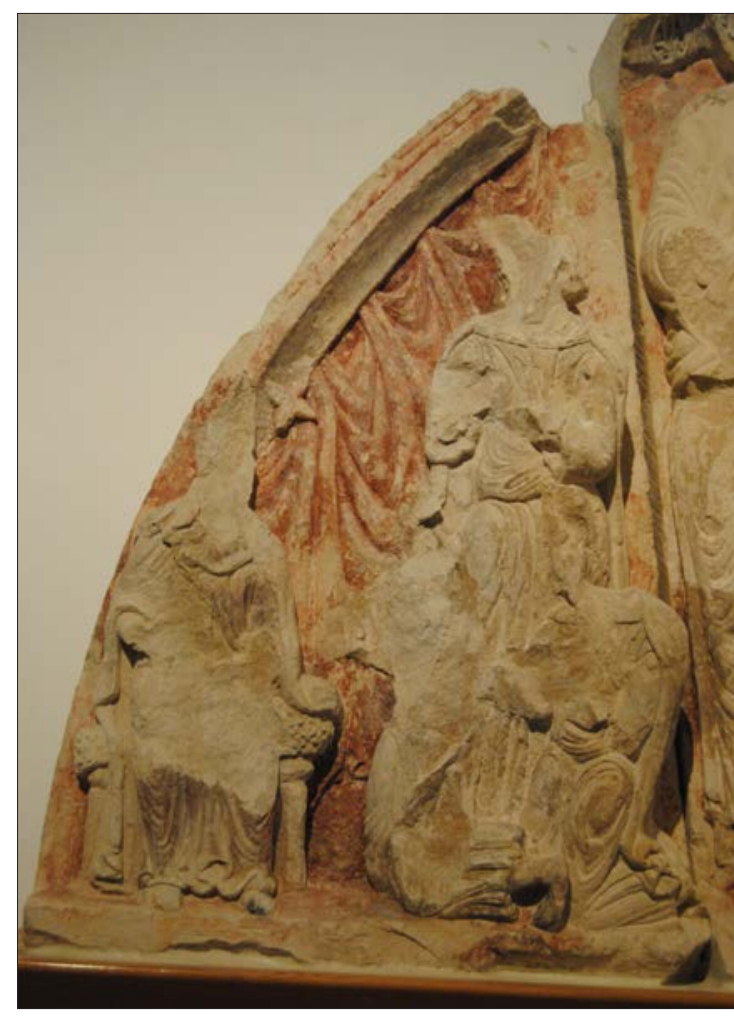

FIGURA 6. DETALLE DE LA ADORACIÓN DE LOS MAGOS. Fotografía: Fernando García Gil
Ana y san José con las tórtolas. Además se elige para la representación, como allí se narraba, el momento en el que Simeón alza sus brazos para tomar al Niño, plasmando así un mismo instante en los dos soportes, tanto en el manuscrito hispano como en el tímpano. La variante iconográfica utilizada, a pesar de no ser habitual en el ámbito hispano, no es exclusiva de Silos sino que tiene un origen bizantino y llegó a extenderse por buena parte del territorio europeo durante el siglo $\mathrm{XII}^{38}$.

El análisis de la Presentación en el Templo, como conclusión, respalda la consideración de la liturgia hispana como fuente del programa iconográfico, ya que es el único de los usos litúrgicos en los que tiene sentido la posición central de la escena.

\section{ADORACIÓN DE LOS MAGOS}

La escena de la Adoración de los Magos ocupa el ángulo izquierdo del tímpano y, aunque cuenta con sectores muy degradados, aún pueden intuirse la mayor parte sus detalles. En primer lugar destaca, en el borde del tímpano, la representación de la Virgen sentada en un trono con el Niño en sus rodillas y una estrella de cuatro puntas sobre sobre su cabeza. Frente a ellos aparecen las figuras de dos magos arrodillados y uno de pie, en cuyos restos aún pueden intuirse las ricas túnicas y los regalos que portaban en sus manos (FIGURA 6).

En el Liber Commicus este pasaje es el que se recoge justo después de la Presentación y pertenece al Apparitione Domini del 6 de enero. La liturgia hispana celebraba este día tres acontecimientos considerados como epifanía; la Adoración de los Magos, el Bautismo y las Bodas de Caná39, aunque el Liber Commicus sólo recogerá aquí el pasaje de los Magos, apareciendo las otras dos epifanías en las partes del manuscrito vinculadas a sus respectivos sacramentos (bautismo y matrimonio). El acontecimiento se recoge en la página 43 (Mateo 2, 9-II):

Ellos, después de oír al rey, se pusieron en camino. La estrella que habían visto en el Oriente iba delante de ellos, hasta que llegó y se detuvo encima del lugar donde estaba el niño. Al ver la estrella, se llenaron de inmensa alegría. Al entrar en la casa, vieron

38. Este modelo iconográfico podemos encontrarlo, por ejemplo, en la capilla Palatina de Palermo, en el sacramentario de Drogo o en las pinturas de la sala capitular de Sigena, ver: Ocón ALONSO, Dulce: op. cit., p. 333.

39. Ivorra Robla, Adolfo: Misal hispano-mozárabe. Barcelona, Centre de Pastoral litúrgica, 2015, pp. 88 y 92. 
al niño con María, su madre. Entonces se postraron y lo adoraron; abrieron luego sus cofres y le ofrecieron dones de oro, incienso y mirra ${ }^{40}$.

La Adoración de los Magos es un pasaje iconográfico que alcanzó una importante difusión en la escultura románica ${ }^{4 \mathrm{I}}$, encontrando representaciones geográficamente cercanas a Silos que, a diferencia de lo que sucede en el tímpano, incluían la figura de san José y prescindían de la representación de la estrella, apareciendo así en los relieves de Pineda de la Sierra, Villasana de Mena o Butrera ${ }^{42}$. El ejemplo que conservamos en la portada de Silos se va a alejar de este modelo iconográfico difundido en su región, optando por la representación de la escena según la descripción de Mateo que aparecía en manuscrito, lo que suponía prescindir de la figura de san José, que no se citaba allí, e incluir la representación de la estrella sobre el Niño como se recoge en el fragmento. Del mismo modo resulta interesante la representación de los dos Magos arrodillados, algo que también coincide con la descripción del texto, donde se citan postrándose en plural, y que Esther Lozano atribuía a una creación iconográfica de este tímpano que, desde aquí, se difundiría a obras de Soria, Ahedo de Butrón o Cerezo de Río Tirón ${ }^{43}$.

Podemos concluir, por tanto, que nos hallamos ante una variante iconográfica muy concreta que, pese a la variedad de fuentes en las que podía inspirarse ${ }^{44}$, va a optar por representar el pasaje de la misma forma en la que se describía en el fragmento del manuscrito, pudiendo ser el origen, además, de una variante iconográfica que llegará hasta algunas obras cercanas.

\section{LAS BODAS DE CANÁ}

A nivel formal es muy poco lo que podemos aportar sobre la arquivolta de las Bodas de Caná, ya que de este sector no hemos conservado ningún vestigio material. Únicamente sabemos de su existencia gracias a la descripción de Nebreda, quien indicaba que existía «... en otro alto [un arco] las bodas del architriclino». La elección del pasaje representado constituye una excepción en el románico, ya que estamos ante el único ejemplo en el que la escena adquiere un desarrollo iconográfico significativo dentro de una portada.

40. Original en latín: «Qui quum audissent regem, abierunt. Et ecce stella, quam viderant in orientem, antecedebat eos, usque dum veniens staret supra, ubi erat puer. Videntes autem stellam gavisi sunt gaudio magno valde. Et intrantes domum inviderunt puerum cum maría matre eius et procidentes adoraberunt eum: et apertis tesauris suis, obtulerunt ei munera, aurum et tus et myrrham». Traducción tomada de: Biblia de Jerusalén, Ed. Desclée de Brouwer, 2009.

41. Rodríguez Peinado, Laura: «La Epifanía», Revista Digital de Iconografía Medieval, 4/8 (2012), pp. 27-44.

42. Rodríguez MontAÑÉS, José Manuel: «La iconografía en la escultura monumental románica burgalesa», en El arte románico en el territorio burgalés. Burgos, Universidad Popular para la Educación y Cultura de Burgos, 2004, p. 186.

43. LozAno López, Esther: «Sobre las peculiaridades del ciclo de la Infancia de Cristo en Santo Domingo de Soria», en Modelos, intercambios y recepción artística: de las rutas marítimas a la navegación en red. XV Congreso Nacional de Historia del Arte. Palma de Mallorca, CEHA, Universitat de les Illes Balears, 2008, vol. 1, pp. 115-116.

44. Puede derivar de fuentes muy diversas como el evangelio de san Mateo, el Protoevangelio de Santiago, el Pseudo-Mateo, el evangelio Árabe de la Infancia o el evangelio Armenio de la Infancia; Rodríguez PeINAdo, Laura: op. cit., p. 30. 
En el Liber Commicus la lectura, pese a ser una de las epifanías que la liturgia hispana celebraba durante el Aparittione Domini del 6 enero, aparece incluida en el sacramento del matrimonio en las páginas 294 y 295. El hecho de que aparezca desplazada en el manuscrito no debe llevarnos a pensar que fuese una festividad ajena al monasterio, ya que la celebración de las tres epifanías el 6 de enero es un hecho general tanto a la liturgia hispana como a la romana. Su desplazamiento, al igual que ocurre con el Bautismo ${ }^{45}$, posiblemente esté vinculado al hecho de que estas dos celebraciones no se recogen nunca en la liturgia hispana como lectura de los evangelios sino como oraciones que las anunciaba ${ }^{46}$, encontrándose así en otras fuentes litúrgicas hispanas como el Missale Gothicum o el Misal Hispano-Mozárabe ${ }^{47}$. El Liber Commicus, sin embargo, no incluye oraciones, sino que únicamente contiene lecciones, epístolas y evangelios, por lo que las lecturas del Bautismo y las Bodas de Caná se recogen en sus respectivos sacramentos, lo que no implica que no fuese una celebración propia del Aparittione Domini del 6 de enero, ya que necesariamente tuvo que serlo en cualquiera de los usos litúrgicos practicados, ya fuese el hispano o el romano.

Volviendo a la relación entre la portada y el manuscrito, y considerando que las relaciones formales son imposibles al carecer de restos materiales, debemos recordar que la mera existencia del pasaje fue otro de los aspectos que causó problemas para la justificación del programa iconográfico como un ciclo de Infancia. La escena de las Bodas de Caná, en este sentido, implicaba un episodio de la vida adulta de Cristo que intentaba justificarse por constituir un testimonio divino que podría vincularse, por tanto, con los otros episodios representados en el tímpano ${ }^{48}$. Sin embargo, si nos alejamos de esta teoría y volvemos a pensar en el rito hispano como fuente de la portada, la presencia de la escena adquiere sentido por sí misma, ya que en ambos soportes va a ser el pasaje que se sitúa entre los episodios de los Magos y los Inocentes, mostrando así una representación exacta del orden de celebraciones en la liturgia hispana.

El posible modelo de representación utilizado, ante la ausencia de ejemplos similares en portadas románicas, debemos interpretarlo a través de tipos iconográficos que pudieran ser extrapolables ${ }^{49}$, entre los cuales el modelo más próximo

45. El Bautismo era la tercera epifanía y su ausencia en este programa iconográfico no debe atribuirse necesariamente a un rechazo del pasaje, sino que es probable que se deba al desconocimiento actual de los relieves completos, sobre los cuales Nebreda solo hizo descripciones generales que no se detienen en los detalles. También se alude a esta posibilidad en: VALDEZ DEL ÁLAMO, Elizabeth: «Witnesses...», p. 228. Otras portadas románicas representan unidas las tres epifanías, como sucede, por ejemplo, en la portada de Notre Dame Du Port (Clermont-Ferrand).

46. Las oraciones hispanas lo anunciaban así: «... hoy quisiste ser adorado por los tres magos. Hoy no dudaste en ser bautizado en las aguas del Jordán por medio de tu siervo. Y en una boda convertiste en vino sabroso el agua de las vasijas...». Fragmento de la Oratio Post Gloriam con la que se abre el Aparittione Domini en el Misal hispanomozárabe. IVOrRa Robla, Adolfo: Misal hispano..., p. 88.

47. LorenzanA, Francisco: Missale Gothicum secudum regulam Beati Isidori. Roma, Antonio Fulgoni, 1804, pp. 154155. Ivorra Robla, Adolfo: Misal hispano..., pp. 88 y 92.

48. YARZA LUACES, Joaquín: op. cit., p. 344; VAldez del Álamo, Elizabeth: «Witnesses...», p. 228. Esther Lozano aludía a que su presencia podía justificarse como alusión a una homilía de Cromacio de Aquilea que cita las Bodas de Caná, aunque reconocía no tener constancia de su utilización en Silos; LozANo LópEz, Esther: «Tradición e innovación: el ciclo de la Matanza de los Inocentes en el románico hispano», Anales de historia del arte, $n^{\circ}$ extra 1 (2010), p. 281, nota 26.

49. El modelo iconográfico más cercano sería el de la Última Cena, con el que habitualmente comparte la mayor parte de los elementos formales. Rodríguez Velasco, María: «Tipos iconográficos de la Última Cena y 
podría ser la representación de la Última Cena que ocupa la mitad de la arquivolta de Moradillo de Sedano, obra muy relacionada con el segundo taller de Silos y que podría ser similar a la composición utilizada aquí, a la que debían haberse añadido algunas escenas con el milagro del vino que permitieron a Nebreda la interpretación del pasaje.

La representación de las Bodas en el programa iconográfico de la portada, como conclusión, debe interpretarse como parte de la secuencia narrativa del ciclo de Navidad, lo que justificaría que la escena aparezca unida a los pasajes de la Infancia ya que, como defendemos, estaría representado un ciclo de celebraciones preestablecido en la liturgia hispana y no pasajes vinculados a una etapa concreta de la vida de Cristo.

\section{LA MATANZA DE LOS INOCENTES}

La existencia de una arquivolta que representaba el episodio de la Matanza de los Inocentes la conocemos gracias a la descripción de Nebreda, pero también por la existencia de una dovela que, de forma consensuada, se atribuye a este conjunto escultórico (FIGURA 7). Aquel fragmento, hoy muy degradado, muestra a una mujer protegiendo a su hijo de un personaje casi desaparecido que se situaba frente a ellos. A nivel plástico existe una relación directa con los artistas que trabajan en el tímpano, utilizando el mismo volumen redondeado, la riqueza de los pliegues que se pegan al cuerpo y la originalidad de las posturas, lo que nos hace pensar en el trabajo de mismo taller.

La Matanza de los Inocentes, durante el románico, desarrolló una iconografía bastante homogénea centrada, principalmente, en los enfrentamientos entre soldados y madres protegiendo a sus hijos, un modelo de representación que alcanzó todo el románico europeo con ejemplos similares en el Pórtico Real de Chartres, la portada de la catedral de Poitiers o el peine de Saint-Albans ${ }^{50}$. Ese modelo de representación es el que podemos encontrar, también, en Burgo de Osma, Santo Domingo de Soria y Moradillo de Sedano, obras muy vinculadas a los talleres de Silos que presentan el pasaje a través de soldados con cota de malla que se enfrentan a mujeres en diferentes actitudes, un recurso similar al que aparece en la dovela conservada. La existencia de una arquivolta completa con este tema en Santo Domingo de Soria nos ofrece un modelo que sería extrapolable a nuestra portada ${ }^{5 \mathrm{I}}$.

En el Liber Commicus La Matanza de los Inocentes se celebraba durante el Allisione Infantum (8 de enero) y era el final del denominado Tiempo de Navidad de la liturgia hispana. El episodio constituía, en el antiguo rito, el cierre de aquel ciclo

simbolismo eucarístico en las imágenes de la última cena», Revista Digital de lconografía Medieval, 8/16 (2016), pp. 119-142.

50. García García, Francisco de Asís: «La Matanza de los Inocentes», Revista Digital de Iconografía Medieval, 3/5 (2011), pp. 23-37.

51. Algunas particularidades que suelen incorporarse al pasaje y que, por tanto, podrían haber existido en la portada son las escenas del diablo aconsejado a Herodes y la Huida a Egipto. LozANo López, Esther: Un mundo en imágenes... 
litúrgico al igual que sucedía en la portada. Esta coincidencia en la posición de las escenas no existiría si pensásemos en la liturgia romana como fuente del programa decorativo, ya que allí la celebración se traslada al 28 de diciembre y, de haber inspirado esta obra, tendría que haberse situado después de la Adoración de los Pastores.

Esta consideración de la Matanza de los Inocentes como final de la Navidad hispana nos permite situar el programa decorativo de la portada dentro de un ciclo litúrgico muy concreto de solo catorce días y que iría, tomando como referencia el antiguo rito, desde el 25 de diciembre al 8 enero. El hecho de que todas las escenas representadas se concentren en un periodo litúrgico tan corto y lo hagan, además, en el orden exacto de celebraciones, apoya la hipótesis que señala a la liturgia hispana como la probable inspiración del programa decorativo.

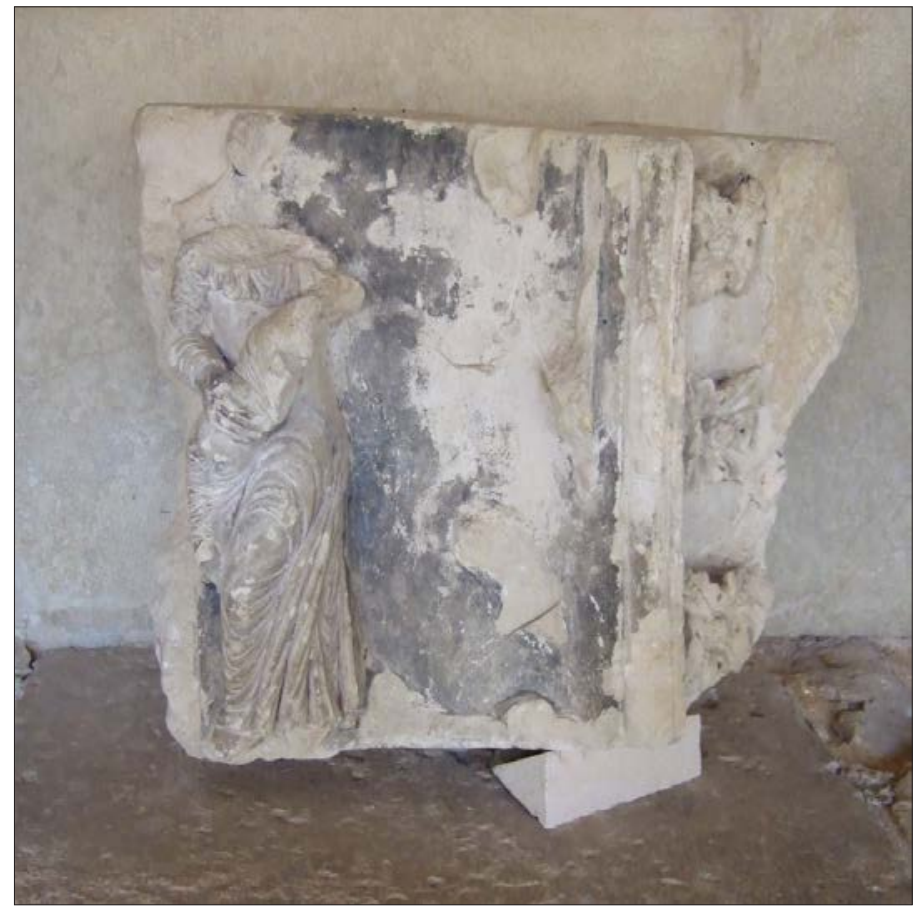

FIGURA 7. DOVELA CON ESCENA DE LOS INOCENTES. ACTUALMENTE EXPUESTA EN EL CLAUSTRO DE SILOS. Fotografía del autor

\section{FUNCIÓN Y SIGNIFICADO DEL PROGRAMA DECORATIVO DE LA PORTADA}

Desde el hallazgo del tímpano se han planteado distintas hipótesis para interpretar el significado y el sentido del programa decorativo, encontrando propuestas que van desde los vínculos con la fiesta de la Purificación hasta las interpretaciones eucarísticas ${ }^{52}$. Sin embargo, estas propuestas suponen consideraciones generales que serían aplicables tanto al monasterio de Silos como a muchos otros centros

52. Valdez del Álamo, Elizabeth: «Witnesses...», p. 228; Ocón Alonso, Dulce: op. cit., pp. 340-343. 
monásticos, lo que dejaría sin respuesta el hecho de que el programa decorativo se limite exclusivamente a Silos, algo extraño si tenemos en cuenta la amplia difusión de sus modelos iconográficos ${ }^{53}$. La excepcionalidad del conjunto y la ausencia de paralelos artísticos nos invitan a buscar circunstancias intrínsecas del propio monasterio que justificarían que el programa decorativo utilizado aquí no tuviera sentido más allá de sus muros, lo que explicaría la ausencia de este modelo iconográfico en otras portadas románicas.

En este sentido debemos destacar la propuesta de Dulce Ocón ${ }^{54}$, cuya investigación sobre el significado de la portada será la base de nuestra interpretación. La autora planteó la posibilidad de que el sentido del mensaje fuese la relación del poder espiritual y el laico, ya que la Presentación se encontraba simbólicamente unida a las ceremonias de recepción en el templo de reyes y gobernantes. La fuente litúrgica que atribuye a esa relación sería la profecía de Malaquías que, además, aparece en Silos recogida en el Liber Commicus (página 7) de la siguiente forma (Malaquías, 3:I): «Ecce ego mittam angelum meum et preparabit viam ante faciem meam»

La relación entre la escena y la profecía consiguió documentarla en el propio monasterio a través de un Misal del siglo XIII (París, B.N. NAL 2I94) que, en su folio 64v., decoraba la profecía de Malaquías con una miniatura de la Presentación en el Templo que repetía el modelo existente en el tímpano ${ }^{56}$. Esta investigación de Dulce Ocón confirma la relación, dentro de los propios muros del monasterio, entre la profecía y el pasaje, además de volver a remitirnos al Liber Commicus como fuente relacionada con la portada.

Una vez interpretado el mensaje como la posible representación de una ceremonia de recepción en el templo, quedaba aún por definir a qué poder laico aludía la escena, una cuestión que la autora consideró vinculada al poder real, como una representación que simbolizaría la recepción de los reyes en la iglesia. Esta interpretación adquiere un pleno sentido con la realidad intrínseca del monasterio y con el espacio de la propia portada ya que, a finales del siglo XII, los crecientes vínculos con la realeza motivaron que el pórtico que cobijaba este acceso se decorase con un programa que incluía las figuras reales como símbolo de la unión entre el monasterio y los reyes ${ }^{57}$. De esta forma la portada de la Navidad encontraría su significado dentro un programa más amplio, el cual estaría dedicado a los vínculos

53. Durante la segunda mitad del siglo XII las creaciones del segundo maestro de Silos se difundieron por gran parte del territorio peninsular, ver: Boto Varela, Gerardo: Ornamento sin delito...; De Charette, Charlotte: La diffusion...; LozAno López, Esther: «Maestros castellanos...»; Boto VArelA, Gerardo: Salamanca-Ciudad LinealPalamós: Las arcadas claustrales de Mas del Vent. Salamanca, Universidad de Salamanca, 2018, p. 125.

54. Ocón Alonso, Dulce: op. cit., pp. 344-348.

55. «Voy a enviar a mi mensajero a allanar el camino delante de mí». Traducción tomada de: Biblia de Jerusalén, Ed. Desclée de Brouwer, 2009.

56. Ocón Alonso, Dulce: op. cit., p. 347.

57. FRONTÓN SIMON, I.: «Propaganda y autoafirmación de una institución monástica medieval: aproximación al programa iconográfico del pórtico del monasterio de Silos», Boletín del Museo e Instituto Camón Aznar, 71 (1998), pp. $173-200$. 
que el monasterio estableció con la realeza, provocando que su mensaje no tuviera sentido fuera de la propia iglesia de $\mathrm{Silos}^{5}$.

Sin embargo, existe otro poder laico que podría haber sido el objeto del mensaje, ya que la propia autora indicaba que la ceremonia aludida en la profecía de Malaquías se dirigía tanto a reyes como a gobernantes que, en este segundo caso, estarían encarnados por el concejo de la villa como responsables del ordenamiento jurídico local. En este sentido, las relaciones son más sugestivas pero, lamentablemente, la fuente en la que se basan es un documento del año I536, un siglo después de que la villa hubiese roto relaciones con el monasterio ${ }^{59}$, lo que nos obliga a plantearlo con una cierta prudencia. Aquel documento, el más antiguo conservado del concejo de Silos, describe la celebración para la elección de cargos de esta forma:

\begin{abstract}
Primeramente que en día de anno nuevo de cada un anno por la mañana se tanna una campana públicamente por manera que sea notorio a todo el pueblo que se quieren nombrar officiales... e tanniendo de yr a iglesia donde se tanniere e allí todos juntos hagan decir una misa...

Ytem, que en acabando de decir de la dicha misa luego los dichos justicia e regimiento y los otros officiales suso dichos se junten públicamente a la puerta de la dicha iglesia en parte donde puedan ser vistos de todas e qualquier persona que lo quisiere ver ${ }^{60}$.
\end{abstract}

Cuando se redacta el documento el concejo ya se había desligado del monasterio y se había trasladado a la iglesia de San Pedro, sin embargo, si imaginásemos aquella celebración un tiempo atrás, aún bajo la tutela del abad y con la iglesia del monasterio como templo parroquial, el acto hubiese tenido lugar bajo la puerta que analizamos ${ }^{6}$. Aquí se da una coincidencia doble y es que concuerdan la fecha de celebración, el i de enero tanto para el oficio civil como para la Presentación, y el significado de los dos actos, ya que ambos aluden la presentación pública de los elegidos. Por tanto, tenemos dos celebraciones documentadas, la Presentación y la elección de cargos, que se celebran en una misma fecha, el I de enero, y que tendrían lugar en un mismo espacio, la portada norte del monasterio. Además, como indicábamos, ambos actos se centraban en la presentación pública de los elegidos (en el sentido espiritual y laico) lo que coincidiría con aquella profecía de Malaquías que

58. La relación con la realeza fue uno de los pilares básicos del auge del monasterio que, con esta intensidad, se repetirá en muy pocos centros. En el siglo XII más de la mitad de sus recursos procedía de las donaciones de la realeza y la nobleza, ver: PALAcios PALOMAR, César: Patrimonio artístico y actividad arquitectónica del monasterio de Silos 1512-1835. Burgos, Abadía de Silos, 2000, p. 22.

59. La villa de Silos fue un núcleo de población bajo jurisdicción abacial como parte de un señorío monástico. El monasterio era dueño del núcleo de población y receptor de sus privilegios, además la iglesia monástica actuaba como iglesia parroquial y el abad debía estar presente en algunas reuniones del concejo. La independencia de la villa no se consiguió hasta 1445, ver: ANTOLín MinAYA, Rodrigo: Reconstrucción de la galería porticada de Santo Domingo de Silos (Burgos), (Trabajo Fin de Máster inédito), UNED, 2018, pp. 36-38 y 78-81. Disponible en: http://e-spacio.uned. es/fez/view/bibliuned:master-GH-MTAIHAG-Rantolin

6o. SÁnchez Domingo, Rafael: Los ordenamientos jurídicos locales de la Sierra de la Demanda: derecho histórico, comunalismo y señoríos. Burgos, Universidad de Burgos, 2007, p. 571.

61. Esta portada era el principal acceso desde la villa de Silos y se encontraba precedida de un pórtico donde se desarrollarían, al menos puntualmente, actos civiles vinculados a su ordenamiento, ver: ANTOLín MinAYA, Rodrigo: op. cit., pp. 75-81. 
Dulce Ocón consiguió vincular al modelo iconográfico de la Presentación: «Voy a enviar a mi mensajero a allanar el camino delante de mí».

La portada, por tanto, tendría un valor simbólico con el que el monasterio intentaría plasmar la superioridad de la celebración espiritual sobre la civil, un reflejo de la situación de dependencia del concejo que se daba desde la concesión del fuero en II36, momento en el que la villa quedó supeditada al poder del monasterio. Además, la situación nos volvería a mostrar una realidad intrínseca a Silos, ya que la relación entre la abadía y su villa es una circunstancia propia que justificaría, por tanto, que un programa decorativo con esa finalidad no tuviera sentido lejos del monasterio.

Lamentablemente, y pese a las coincidencias, debemos reiterar que la datación tardía de la fuente nos obliga a recibir esta última propuesta con mucha prudencia, ya que es complicado extrapolar aquella realidad de 1536 al siglo XII. Sin embargo, la coincidencia en las fechas, el lugar y el significado de las celebraciones, hacen que hayamos considerado oportuno, al menos, presentar la idea.

\section{CONCLUSIÓN}

La forma en la que los usos litúrgicos hispanos llegan a condicionar diferentes programas decorativos del románico es una de las cuestiones que deben valorase de este trabajo, ya que su consideración es un aspecto que va más allá de la portada que ha sido objeto de estudio y que puede ser extensible a otras creaciones de los siglos XII y XIII. La existencia de un rito propio hasta finales del siglo XI suponía unas particularidades litúrgicas que, obviamente, condicionaron los modelos iconográficos del románico más temprano. Sin embargo, el complejo proceso de adopción de la nueva liturgia romana provocó que algunos conceptos anteriores siguieran vigentes durante el apogeo del románico, incluso en aquellos centros que, como el caso de Silos, habían aceptado de forma rápida el nuevo rito romano. Estas circunstancias hacen que, en el románico hispano, puedan aparecer programas decorativos cuya referencia iconográfica se encuentra en los usos litúrgicos antiguos.

El uso de aquellas fuentes iconográficas no debe vincularse a una continuidad de la liturgia hispana sino, más bien, a la pervivencia de algunos usos y costumbres que llevaban asociada la conservación de los valiosos manuscritos antiguos. El hecho de que algún códice hispano sirviese de fuente iconográfica para esta portada datada a finales del siglo XII nos habla de la pervivencia que tenían aquellos manuscritos un siglo después del cambio de liturgia.

Pasando ahora a la portada norte de Silos, verdadero objeto de estudio de este trabajo, debemos recordar que nos hallamos ante un ejemplo único en el arte románico, cuyo programa iconográfico no se repite en ninguna otra portada conservada. De hecho, algunas escenas no encuentran paralelos artísticos ni siquiera al considerarlas de manera individual, pues no conservamos ningún otro ejemplo donde la escena de la Presentación sea la que preside un tímpano románico, ni ninguna otra obra donde las Bodas de Caná tengan un desarrollo amplio en una arquivolta. 
Para el análisis iconográfico partíamos de una propuesta que se había mantenido vigente durante más de cuatro décadas y que llevaba a la denominación de estas esculturas como Tímpano de los Testimonios y a la consideración de su programa iconográfico como un ciclo de Infancia. Esta propuesta imperante presentaba algunos elementos de compleja justificación, los cuales se van diluyendo si empezamos a considerar los manuscritos litúrgicos hispanos como la fuente iconográfica de la portada.

Al relacionar las esculturas con el Liber Commicus silense, presente en el monasterio desde 1067, pudimos observar cómo existe, en el ciclo dedicado a la Navidad, una secuencia idéntica de pasajes y celebraciones que, además, recurren a unos mismos modelos de representación en la mayor parte de los episodios. Estas relaciones nos permiten intuir que el mensaje iconográfico que se traslada a la portada debe ser una representación del Tiempo de Navidad de la liturgia hispana y no un ciclo de Infancia como se ha defendido hasta ahora. Por este motivo, y considerando la propuesta iconográfica que hemos presentado, debemos hallarnos, como indicaba el propio título del trabajo, ante una Portada de la Navidad, en cuya concepción pesaron circunstancias internas del propio monasterio que provocaron que apareciese un modelo iconográfico sin precedentes en el arte románico y que, de la misma forma, tampoco va a trasladarse después a ninguna otra portada esculpida. 


\section{BIBLIOGRAFÍA}

Aguilera López, Salvador, Ivorra Robla, Adolfo: Calendario litúrgico del Rito Hispanomozárabe. Año litúrgico 2013-20I4. Instituto Superior de Estudios Teológicos San Ildefonso, Toledo, 20I3.

Antolín Minaya, Rodrigo: Reconstrucción de la galería porticada de Santo Domingo de Silos (Burgos), (Trabajo Fin de Máster inédito), UNED, 2018.

BANGo ToRviso, Isidro: «La iglesia antigua de Silos: del prerrománico al románico pleno», en El románico en Silos: IX centenario de la consagración de la iglesia y el claustro, I088-1988. Santo Domingo de Silos, Abadía de Silos, I990, pp. 317-362.

BANGo ToRviso, Isidro: «San Pelayo de Perazancas: Las imágenes de un calendario románico organizadas según la vieja liturgia hispana, y su contexto en el conjunto del programa iconográfico», Anales de Historia del Arte, 4 (I993-I994), pp. 545-558.

Ben-Pechat, Malka: «L'iconographie de l'Ascensión dans le programme des six bas reliefs sous une lumière théologique et liturgique», en El románico en Silos. IX centenario de la consagración de la iglesia y el claustro. Santo Domingo de Silos. Abadía de Silos, I990, pp. 465-47I.

Boto VARElA, Gerardo: Ornamento sin delito: los seres imaginarios del claustro de Silos y sus ecos en la escultura románica peninsular. Burgos, Abadía de Silos, 200 I.

Boto VARELA, Gerardo: «El santo de Silos: monumenta domésticos, hechuras hagiográficas y expansión devocional (s. XI-XIV)», en Hagiografía peninsular en els segles medievals. Lleida. Universitat de Lleida, 2008, pp. 33-68.

Boto Varela, Gerardo: Salamanca-Ciudad Lineal-Palamós: Las arcadas claustrales de Mas del Vent. Salamanca, Universidad de Salamanca, 2018.

Castresana López, Álvaro: «Un beato de piedra: el tímpano de Moradillo de Sedano (Burgos)», Estudios mirandeses: Anuario de la fundación cultural «Profesor Cantera Burgos», 35 (2019), pp. IOO-I39.

De Charette, Charlotte: La diffusion de l'art du second atelier de sculpture de Silos dans le nord de l’Espagne (Tesis doctoral inédita), Université Michel de Montaigne - Bordeaux III, 2014.

Del Amo Horga, Luz Marina: «La iconografía de la Navidad. Ciclo de la Navidad o Encarnacion», en Arte, religiosidad y tradiciones populares. San Lorenzo de El Escorial, Real Centro Universitario Escorial-María Cristina, 2009, pp. 233-252.

Ferotin, Marius: Histoire de l'Abayye de Silos. París, Ernest Léroux, I897.

Ferotin, Marius: «Leccionario visigótico de la iglesia de Toledo», Boletín de la Real Academia de la Historia, 46 (I905), pp. 305-310.

FERnÁndez De LA Cuesta, Ismael: «La irrupción del canto gregoriano en España. Bases para un replanteamiento», Revista de Musicología, 8/2 (I985), pp. 239-248.

FERnÁNDEZ De La Cuesta, Ismael: Música y liturgia: el tímpano de la iglesia de Silos. Biblioteca Virtual Miguel de Cervantes, Alicante, 2006.

Frontón Simón, Isabel: «El pórtico de la iglesia románica del monasterio de Silos: Datos para la reconstrucción iconográfica de su portada exterior», Boletín del Museo e Instituto Camón Aznar, 64 (1996), pp. 65-98.

Frontón Simón, Isabel: «Propaganda y autoafirmación de una institución monástica medieval: aproximación al programa iconográfico del pórtico del monasterio de Silos», Boletín del Museo e Instituto Camón Aznar, 7I (1998), pp. I73-200. 
GaILLARD, Georges: «L'Église et le cloître de Silos: dates de construction et de la décoration», Bulletin Monumental, 9I (I932), pp. 39-80.

García García, Francisco de Asís: «La Matanza de los Inocentes», Revista Digital de Iconografía Medieval, 3/5 (201I), pp. 23-37.

Gómez Gómez, Agustín: «La iconografía del parto en el arte románico hispano», Príncipe de Viana, 213 (1998), pp. 79-102.

GonzÁlez Hernando, Irene: «El nacimiento de Cristo», Revista Digital de Iconografía Medieval, 2/4 (2010), pp. 4I-59.

Gros I Pujol, Miquel: «Las tradiciones litúrgicas medievales en el noroeste de la península», en IX Centenário da dedicaçâo da Sé de Braga. Congresso Internacional. Actas. Vol. III: Teologia do Templo e Liturgia Bracarense. Braga, Universidade Católica Portuguesa, I990, pp. I03-II5.

Ivorra Robla, Adolfo: Misal hispano-mozárabe. Barcelona, Centre de Pastoral litúrgica, 2015.

Lorenzana, Francisco: Missale Gothicum secudum regulam Beati Isidori. Roma, Antonio Fulgoni, I804.

Lozano López, Esther: Un mundo en imágenes: La portada de Santo Domingo de Soria. Madrid, Fundación Universitaria Española, 2006.

LozANo López, Esther: «Sobre las peculiaridades del ciclo de la Infancia de Cristo en Santo Domingo de Soria», en Modelos, intercambios y recepción artística: de las rutas marítimas a la navegación en red. XV Congreso Nacional de Historia del Arte. Palma de Mallorca, CEHA, Universitat de les Illes Balears, 2008, vol. I, pp. Io9-II9.

LOZANo López, Esther: «Tradición e innovación: el ciclo de la Matanza de los Inocentes en el románico hispano», Anales de historia del arte, extra I (2010), pp. 275-29I.

LozANo López, Esther: «Maestros castellanos del entorno del segundo taller silense: repertorios figurativos y soluciones estilísticas», en Neue Forschungen zur Bauskulptur in Frankreich und Spanien. Berlín, Frankfurt am Main, 2010, pp. 197-2II.

Morin, Germain: «Liber Comicus; sive, Lectionarius missae quo toletana Eclessia ante annos mille et ducent usutebatur». Universidad de Toronto, 1893.

Ocón Alonso, Dulce: «La Presentación en el templo de la puerta norte de la iglesia del monasterio de Santo Domingo de Silos y su relación con algunos paradigmas artísticos del mundo mediterráneo», en Alfonso VIII y Leonor de Inglaterra: confluencias artísticas en el entorno de I200. Madrid, Universidad Complutense de Madrid, 20I7, pp. 315-356.

Orduña Cuevas, María: «Una aproximación a la topografía claustral del monasterio de Santo Domingo de Silos (s. XI-XII)», Revista Historia Autónoma, 6 (2015), pp. II-27.

Palacios Palomar, César: Patrimonio artístico y actividad arquitectónica del monasterio de Silos I5I2-I835. Burgos, Abadía de Silos, 2000.

Palomero Aragón, Félix: «San Sebastián de Silos: la iglesia dedicada o consagrada en torno a Io88 a través de la documentación y los restos arqueológicos», Imago temporis. Medium Aevum, 7 (2013), pp. I39-I74.

PÉREZ, Antonio Manuel: «Fuentes iconográficas de la representación de Cristo del relieve de la Ascensión del Claustro de Silos», Archivo Español de Arte, 320 (2007), pp. 428-440.

PInELL, Jordi: Liturgia hispánica. Barcelona, Centre de Pastoral Litúrgica, I998.

Prado, Germán: Historia del rito mozárabe y toledano. Burgos, Abadía de Santo Domingo de Silos, I928.

Quintana De UÑa, María José: «Los ciclos de Infancia en la escultura monumental románica de Navarra», Príncipe de Viana, 48/18I (1987), pp. 269-298. 
RODRíGUEZ MontAÑÉs, José Manuel: «La iconografía en la escultura monumental románica burgalesa», en El arte románico en el territorio burgalés. Burgos, Universidad Popular para la Educación y Cultura de Burgos, 2004.

Rodríguez Peinado, Laura: «La Epifanía», Revista Digital de Iconografía Medieval, 4/8 (2012), pp. 27-44.

Rodríguez Velasco, María: «Tipos iconográficos de la Última Cena y simbolismo eucarístico en las imágenes de la última cena», Revista Digital de Iconografía Medieval, 8/16 (2016), pp. II9-I42.

Rubio SADIA, Juan Pablo: «Introducción del Rito Romano y reforma de la iglesia hispana en el siglo XI: de Sancho III el Mayor a Alfonso Vl», en La reforma gregoriana en España: seminario de historia de la iglesia. Madrid, Publicaciones San Dámaso, 20II, pp. 54-75.

SÁINZ MAGAÑA, Elena: «Silos y el románico soriano», en El románico en Silos: IX centenario de la consagración de la iglesia y el claustro, Io88-I988. Santo Domingo de Silos, Abadía de Silos, I990, pp. 429-446.

SÁnchez Domingo, Rafael: Los ordenamientos jurídicos locales de la Sierra de la Demanda: derecho histórico, comunalismo y señoríos. Burgos, Universidad de Burgos, 2007.

SÁnchez Domingo, Rafael: «El rito hispano-visigótico o mozárabe: del ordo tradicional al canon romano», en Patrimonio Inmaterial de la Cultura Cristiana. San Lorenzo de El Escorial, Ediciones Escurialenses, 2013, pp. 215-236.

SÁncheZ Mariana, Manuel: «Los códices del monasterio de Silos», Boletín de la Institución Fernán González, 63/203 (1983), pp. 219-236.

Santos Otero, Aurelio: Los evangelios apócrifos. Madrid, Biblioteca de Autores Cristianos, 2005.

SenRa Gabriel y Galán, José Luis: «Santo Domingo de Silos: New Interpretive Suggestions for the Medieval Church (I04I-II43)», en Church, State, Vellum, and Stone: Essays on Medieval Spain in Honor of John Williams. Leiden/Boston, Brill, 2005, pp. 329-372.

SenRa Gabriel y Galán, José Luis: «El monasterio de Santo Domingo de Silos y la secuencia temporal de una singular arquitectura ornamentada», en Siete maravillas del románico español. Aguilar de Campoo, Fundación Santa María la Real, 2009, pp. 193-226.

VALDEZ Del Âlamo, Elizabeth: «Visiones y profecía: el árbol de Jesé en el claustro de Santo Domingo de Silos», en El románico en Silos: IX centenario de la consagración de la iglesia y el claustro, I088-1988. Santo Domingo de Silos, Abadía de Silos, I990, pp. I73-202.

Valdez Del Álamo, Elizabeth: «Witnesses to the Faith in the pórtico of Santo Domingo de Silos», en Imágenes y promotores en el arte medieval: Miscelánea en homenaje a Joaquín Yarza Luaces. Barcelona, Universitat Autònoma de Barcelona, 200I, pp. 22I-229.

Valdez Del Álamo, Elizabeth: Palace of the Mind. The Cloister of Silos and Spanish Sculpture of the Twelfth Century. Brepols Publishers, 2012.

Vivancos Gómez, Miguel: «El oficio litúrgico en Santo Domingo de Silos», en Silos. Un Milenio.Congreso Internacional sobre la Abadía de Santo Domingo de Silos, Tomo I, espiritualidad. Burgos, Universidad de Burgos, 2003, pp. 8I-88.

VONES, Ludwing: «La sustitución de la liturgia hispana por el rito romano en los reinos de la península ibérica», en Hispania Vetus: manuscritos litúrgico-musicales: de los orígenes visigóticos a la transición franco-romana (siglos XI-XII). Madrid, Fundación BBVA, 2007, pp. 43-6o.

WervkMeISTER, Otto Karl: «The Emmaus and Thomas pillar of the cloister of Silos», en El románico en Silos: IX centenario de la consagración de la iglesia y el claustro, I088-I988. Santo Domingo de Silos, Abadía de Silos, I990, pp. I49-I6I. 
Whitehill, Walter Muir.: «The Destroyed Romanesque Church of Santo Domingo de Silos», The Art Bulletin, I4 (1932), pp. 316-343.

YARZA LUACES, Joaquín: «Nuevos hallazgos románicos en el monasterio de Silos», Goya, revista de arte, 96 (1970), pp. 342-345.

ZAPKE, Susana: «Sistemas de notación en la Península Ibérica: de las notaciones hispanas a la notación aquitana (siglos IX-XII)», en Hispania Vetus: manuscritos litúrgico-musicales: de los orígenes visigóticos a la transición franco-romana (siglos XI-XII). Madrid, Fundación BBVA, 2007, pp. 189-244. 


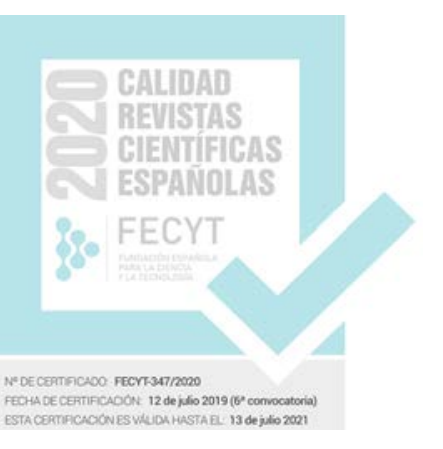

SERIE VII HISTORIA DEL ARTE

REVISTA DE LA FACULTAD DE GEOGRAFÍA E HISTORIA
AÑO 2020

NUEVA ÉPOCA

ISSN: $1130-4715$

E-ISSN 2340-1478

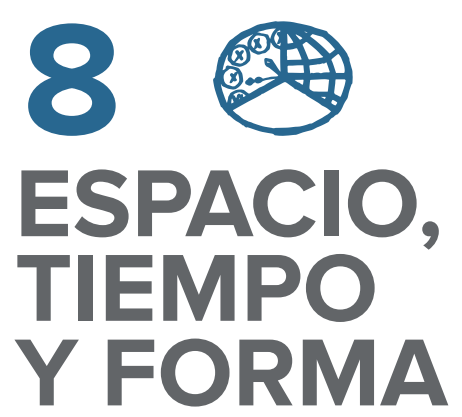

Dossier por Patricia Molins: Feminismo y museo. Un imaginario en construcción. Feminism and museum. An imaginary in construction

15 PATRICIA MOlins (EDITORA INVITADA)

15 Introducción: museos y feminismo. Dentro y fuera · Introduction: Museums and Feminism. In and Out

29 Isabel Tejeda Martín (Autora invitada)

Exposiciones de mujeres y exposiciones feministas en España. Un recorrido por algunos proyectos realizados desde la II República hasta hoy, con acentos puestos en lo autobiográfico . Women's Exhibitions and Feminist Exhibitions In Spain: A Journey Through some Projects Carried out since the $2^{\text {nd }}$ Republic until the Present, with some Biographical Highlights

4.7 Maite Garbayo-Maeztu

Shifting, citing, stumbling: curating as a feminist practice

75 Ana Pol Colmenares y María Rosón Villena

Feminisms

9 Jesús Carrillo y Miguel Vega Manrique

«¿Qué es un museo feminista?» Desacuerdos, negociación y

mediación cultural en el Museo Reina Sofía · «What Is a Feminist Museum?» Disagreements, Negotiation and Cultural Mediation at the Reina Sofía Museum 129 Elena Blesa Cábez, Sara Buraya Boned, Maria Mallol y Mabel Tapia Museo en red y las prácticas del afecto en el Museo Reina Sofía . Doing with Others and Ourselves, for an Institutionality-in-becoming. Museo en red and the Care Practices in Museo Reina Sofía

14. GLORIA G. DURÁN

Perils of Tenderice. Equality Sisterhood Solidarity

171 Rafael Sánchez-Mateos Paniagua

The Crossed Destinies of Impossibility. Gendered Perspectives on the Museum of the Spanish People in the Company of Carmen Baroja y Nessi

203 INMACULADA REAL LÓPEZ

La reconstrucción de la identidad femenina en los museos: la recuperación de las olvidadas . The Reconstruction of Female Identity in the Museums: The Recovery of the Forgotten

«Indias Huancas» de Julia Codesido · «Indias Huancas» by Julia Codesido
251 Ester Alba Pagán y Aneta Vasileva IVanova

el feminismo and Strategies from Museology and Roma Feminism, under the Prism of Covid-19

271 Clara Solbes Borja y María Roca Cabrera

Networks from a Feminist Perspective. The case of «Relecturas»

Museum

285 DOLORES VILLAVERDE SOLAR

siciones y artistas. The Presence of Feminist Art in the CGAC. Selection of Exhibitions and Artists

301 Ane LeKuona Mariscal

El papel de las exposiciones en la escritura de la (androcéntrica)

The Role of Exhibitions in the Writing of the (Androcentric) History of Art of the Basque Country

319 Celia martín Larumbe y Roberto Peña León

Política cultural institucional como medio de transformación. La experiencia en la Comunidad Foral de Navarra · Institutional Cultural Politics as a Means of transformation. An experience in the Comunidad Foral de Navarra

\section{Miscelánea · Miscellany}

343 RODRIGO ANTOLÍn MINAYA La portada de la navidad en la iglesia románica de Santo Domingo De Silos (Burgos): análisis de un programa iconográfico románico inspirado por la - The Christmas Portal in the Romanic Church of Santo Domingo de Silos (Burgos): Analysis of a Romanesque Iconographic Program Inspired by the Hispanic Liturgy

369

gNACIO GONZÁLEZ CAVERO

Referencias sobre el patrimonio arquitectónico en Išbiliya a través de

References on the Architectural Heritage in Išbiliya through the Arab Authors and Documentary Sources between the Emiral and Almoravid Periods

\section{Mercedes Gómez-FERRER}

Domingo de Valencia (1609), obra genovesa encargo del Conde de Benavente . The Tomb of the Venerable Domingo Anadon in the Dominican Convent of Valencia (1609), A Genoese Work Commissioned by the Count of Benavente

\subsection{Manuel Antonio díaz Gito}

de Jan Steen, pintor holandés del Siglo de Oro - Written on the Canvas: Ovid and the Billet-Doux in The Lovesick Maiden by Jan Steen, Golden Age Dutch Painter

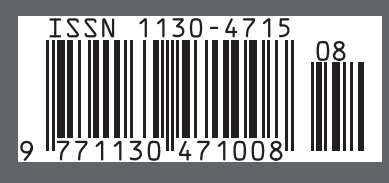


AÑO 2020

NUEVA ÉPOCA

ISSN: 1130-4715

E-ISSN 2340-1478

\section{8 ESPACIO, TIEMPO Y FORMA}

\subsection{Gemma Сово} and Political Practices about the Deceased Prince of Asturias

\subsection{Eduardo Galak}

Distances. Towards an Aesthetic and Political Image-Movement Regime

\subsection{Diego Renart González}

Turtes plásticas dominicanas of Art, Abstraction and Protest in the Dominican Plastic Arts during the First Two Decades of the Trujillo's Dictatorship (1930-1952)

\section{José LUIS de LA NUEZ SANTANA}

Alfons Roig y Manolo Millares en diálogo: los documentos del archivo Alfons Roig (MUVIM, Valencia) · Dialogue between Alfons Roig and Manolo Millares: The Documents of the Alfons Roig Archive (MUVIM, Valencia)

533 FÉlix Delgado López y Carmelo Vega de La Rosa

3 Nuevas visiones fotográficas de Lanzarote: una isla más allá del turismo . New Photographic Visions of Lanzarote: An Island beyond Tourism

55 JOSÉ LUIS PANEA

Del descanso forzado a la cama interconectada como espacio de creación Escenarios posibles desde las prácticas artísticas contemporáneas . From Forced Rest to the Interconnected Bed as a Space for Creation. Possible Stages in Contemporary Art Practices

\section{Reseñas · Book Reviews}

\section{Encarna Montero Tortajada}

FERrER DEL Río, Estefania, Rodrigo de Mendoza. Noble y coleccionista del Renacimiento. Madrid, Sílex Ediciones, 2020

\section{CONSUelo Gómez López}

Juliana Colomer, Desirée, Fiesta y Urbanismo en Valencia en los siglos XVI y XVII, Valencia, Universitat de València, 2019

\section{9 Ӓ́varo Mounk}

SAZATORNIL RUIZ, Luis \& MADRID Álvarez, Vidal de la (coords.), Imago Urbis. Las ciudades españolas vistas por los viajeros (siglos XVI-XIX). Gijón, Ediciones Trea, 2019.

\section{Borja Franco Llopis}

LÓPEZ TERRADA, María José, Efímeras y eternas: pintura de flores en Valencia (1870-1930). Casa Museo Benlliure, del 21 de febrero al 7 de julio de 2019. Valencia, Ajuntament de València, Regidoria de Patrimonio i Recursos Culturals, 2018 